\title{
Access to internal capital, creditor rights and corporate borrowing: Does group affiliation matter?
}

\author{
Chandra Thapa ${ }^{1}$, Sandeep Rao ${ }^{1}$, Hisham Farag ${ }^{2}$,Santosh Koirala ${ }^{2}$
}

(Authors'version of pre-print)

\begin{abstract}
We examine whether the effect of increased creditor rights on corporate borrowing depends on firms' access to internal capital. By exploiting a creditor protection reform in the Indian market, empirical outcomes strongly indicate that strengthening of creditor rights leads to increased corporate borrowing among firms that have constrained access to internal capital compared to business group affiliated firms, which have relatively easier access to internal capital. Further, the increased corporate borrowing by firms with constrained access to internal capital, in the post-reform period, is associated with a greater expansion of real investments, improved operational performance, and better market valuation. Taken together, these findings indicate that expanding creditor rights may aid in improving allocative efficiency.
\end{abstract}

JEL Codes: G32; G34; G38

Keywords: creditor protection; internal capital; standalone firms; business group firms; corporate borrowing; firm performance

\footnotetext{
${ }^{1}$ Chandra Thapa; Sandeep Rao Department of Accounting and Finance, University of Strathclyde, Scotland G4 0QU, United Kingdom

${ }^{2}$ Hisham Farag; Santosh Koirala, Department of Finance, University of Birmingham, B15 2TT, United Kingdom
} 


\section{Introduction}

Does strengthening of creditor rights expand or shrink corporate borrowing? This is an important policy question facing the regulatory domain. The finance literature, however, offers two seemingly opposing economic views on this issue. The first view, which is primarily based on the empirical work of La Porta et al. (1998), conjectures that reforms that empower creditors to efficiently enforce contracts should improve their willingness to lend more. Such an increase in the credit supply should also lower the cost of credit. This, in turn, should improve corporate borrowing and the firm's access to external finance (La Porta et al., 1998). This view has gained empirical support in the literature. For example, Haselmann et al. (2010) show that the lending activities in Central and Eastern European countries experienced a boost following the creation of a collateral registry, which enhanced creditor rights to enforce their contracts. Other previous studies also support the argument that the credit market is enhanced as a result of strong creditor protection (Djankov et al., 2007; Jappelli and Pagano, 2002; La Porta et al., 1998). Taken together, these arguments confirm the economic power theory of credit, which suggests that creditors are more willing to lend when they can enforce their rights more easily (Hart and Moore, 1994; Townsend, 1979).

The second and apparently opposite economic view argues that expansion of creditor rights results in deadweight costs arising from the lenders' supremacy in dictating terms, which undermines the decision-making power and flexibility of firms. The associated higher deadweight costs should then consequently lower debt financing (Vig, 2013). In other words, the strengthening of creditor rights may carry distorted demand and supply side effects. Although creditors may be willing to lend more and at a lower interest rate following higher creditor empowerment, the demand side reaction may have unintended consequences on the loan market because of the lowered willingness of debtors to borrow more. In line with this view, Acharya et al. (2011) empirically show that corporate leverage is lower in countries with 
stronger creditor rights. Further, in a cross-country study, Cho et al. (2014) also demonstrate that firms avoid long-term cash flow commitments to service debts when facing stronger creditor protection. They do so to evade the risk of losing control in the event of financial distress. Other literature on bankruptcy also suggests inefficiencies in the form of firm liquidation bias associated with excessive creditor rights (Aghion et al., 1992; Hart et al., 1997). In summary, this conjecture of deadweight costs predicts that the strengthening of creditor rights may deter firms' willingness to borrow.

Given the two apparently opposing economic views, we extend this debate by exploring the effect of creditor rights on firm's borrowing based on an important corporate heterogeneity, i.e., whether the borrowing firms have constrained access to internal capital or not. To gauge this heterogeneity of firm's access to internal capital, we classify firms based on whether a firm is affiliated with a business group or is a standalone firm with no group affiliation.

The business group affiliation classification has two important features that determine to what extent a firm has access to internal capital. First, existing studies document that firms affiliated with a business group benefit from resources owned by other affiliates in the same group. As business group firms have significant operational and financial interlinkages and are managed by a common group of insiders, they have the advantage of accessing significant internal capital (Gopalan et al., 2007; Hoshi et al., 1991; Shin and Park, 1999). Further, such an affiliation could efficiently allocate the resources within the group (Chang and Hong, 2000). However, no such resource-based advantage is available for unaffiliated standalone firms, which suggests that these firms face a higher level of constraints to access internal capital.

Second, group affiliation could provide a partial substitute for inefficient external financing, which acts as insurance, particularly at times when a firm faces an external financing shock. Testing the financing advantage hypothesis, Khanna and Yafeh (2007) show that group affiliated firms replace expensive external debt with cheaper intragroup loans as a remedy in 
underdeveloped capital markets. The internal capital markets of group affiliated firms, thus, could reduce the transaction costs for group affiliates and supplement the inefficient external capital markets of emerging economies (Chang and Hong, 2000). Further, the negative externality associated with the presence of business group conglomerates could make it more difficult for standalone firms to raise external capital - a factor that could seriously undermine the growth of these independent firms in developing countries that are at intermediary levels of financial development (Almeida and Wolfenzon, 2006). ${ }^{1}$ In summary, business group firms have the flexibility not to seek external borrowing following a regime that strengthens the power of creditors in dictating the terms of borrowing. On the other hand, unaffiliated standalone firms do not have such privilege.

The aforementioned discussion on the heterogeneous access to internal capital argument predicts that compared to business group affiliates, unaffiliated standalone firms should find the expansion of contractual space beneficial. This implies that the standalone firms, relative to business affiliated firms, should opt to borrow more following a positive shift in creditor rights (La Porta et al., 1998). We test this conjecture by exploiting a unique regulatory set-up in India, namely, the Securitization and Reconstruction of Financial Assets and Enforcement of Security Interests Act of 2002 (the SARFAESI Act, henceforth). This reform strengthened creditor rights by making it much easier for lenders to seamlessly take over the management of secured assets and sell them to recover debt obligations. ${ }^{2}$ The SARFAESI Act exogenously provided creditors with the ability to more easily access and dispose debtors' collateral. This suggests that within the above-discussed framework of the economic power theory of credit, the reform provided greater confidence to creditors to lend more, thus expanding the supply side of the credit market.

\footnotetext{
${ }^{1}$ The argument is that the unsecured debt market may become a viable alternative for the group affiliated firms who could lower their secured debt and substitute with the unsecured debt, thus making it more difficult for the otherwise stand-alone firms to access this market segment.

${ }^{2}$ See Section 2 for details.
} 
Using a sample of 1,978 nonfinancial listed firms affiliated with 641 unique businessgroups, along with 3,071 unaffiliated standalone listed firms and exploiting the exogenous variations availed by the SARFAESI Act, our study finds that unaffiliated standalone firms (treated firms henceforth) increase their debt financing more relative to business group firms (comparison firms henceforth) following the creditor rights reform. In terms of economic magnitude, the expansion of creditor rights increases the total borrowing of treated firms in the range of $2 \%$ to $4 \%$ of total assets, depending on the specification. Similar results are documented when we employ treated and comparison groups based on an alternative measure of a firm's access to internal capital, which is the Internal Capital Growth Rate (ICGR). ${ }^{3}$

The main results are robust to a battery of robustness checks, such as the use of different forms of debt structures, different study periods, a propensity score matched difference-indifferences (PSM-DiD) design and employing an unlisted sub-sample of private firms. All these checks strongly suggest that, compared to their business affiliated peers, unaffiliated firms experience a significantly greater increase in corporate borrowing following the creditor rights reform. Additionally, we take advantage of the heterogeneity based on whether a business group has a financial institution as an affiliated member or not. By exploiting this classification, we show that business group affiliated firms with no affiliated financial institution increase debt financing more than those who have the advantage of having an affiliated financial institution.

Our examinations on the implications of increased borrowing show that the treated firms (i.e., standalone financially constrained firms) that borrow relatively more in the post creditor protection regime experience greater improvement in their capital investments, operating performance and market valuation. These findings underscore the positive effect of creditor

\footnotetext{
${ }^{3}$ Lower ICGR firms are considered to be firms with higher constraints to internal capital. See Subsection 5.5.3 for the definition of this variable.
} 
protection in encouraging real investment, financial performance and investment efficiency for firms that otherwise have constrained access to internal capital.

We interpret our findings as evidence that firms that have constrained access to internal capital benefit from the strengthening of creditor rights protection, a view in line with the argument of La Porta et al. (1998) and Haselmann et al. (2010). The findings of our results suggest that the unintended consequences argument of creditor empowerment (Acharya et al., 2011; Vig, 2013), which predicts that a creditor reform has a negative effect on corporate borrowing, could be driven by firms that have easier access to alternative sources of capital, particularly that of the internal capital market. Our overall findings thus suggest that a policy intervention expanding creditor rights is particularly beneficial for firms that have constrained access to internal capital.

Our findings on the implications of increased borrowing are also consistent with the efficient capital allocation argument put forth by Almeida and Wolfenzon (2006), whereby they argue that efficient capital allocation activities are constrained by the extent of financial development of an economy. Their model predicts that, in an economy that is at an intermediary level of financial development, the effect of conglomeration can create a negative externality that makes it more difficult for the nonaffiliated standalone firms to raise the required capital. To this end, our study provides evidence that the expansion of creditor rights improves allocative efficiency by channeling capital to the financially constrained units in an emerging economy (Almeida and Wolfenzon, 2006).

Our study contributes to the ongoing debate on whether an environment of stringent creditor protection encourages or deters corporate borrowing (Acharya et al., 2011; La Porta et al., 1998; Vig, 2013). We add to this literature by focusing on one important firm heterogeneity, i.e., firms' access to internal sources of financing. Contrary to the evidence of lower borrowing being a consequence of the regulatory intervention of expanding creditor rights, as documented 
in previous studies (Vig, 2013), we show that such reforms encourage corporate borrowing among firms with constrained access to internal capital. Thus, from a policy point of view, the results of our findings imply that a regulatory intervention aimed at expanding creditor protection may lead to desired policy outcomes for firms that have constrained access to internal capital. We further highlight the importance of this outcome on expanding real investments, higher valuation and better performance for standalone firms in the post-reform period. As such, we contribute to the literature on the merit of creditor reform by demonstrating the positive effect of expanding creditor rights in improving allocative efficiency in an emerging economy (Wolfenzen and Almieda, 2006).

The rest of the paper is organized as follows. Section 2 elaborates on the SARFAESI Act, which we empirically exploit in this study. Section 3 reviews the existing literature and develops the key testable hypothesis. Section 4 describes the dataset and variables followed by a discussion of the empirical results in Section 5. Finally, Section 6 concludes the paper.

\section{The SARFAESI Act and Creditor Protection in India}

In the Indian context of pre-liberalization era of 1991, debt recovery by creditors through seizure and liquidation of assets was a tedious process. This debt recovery involved lengthy legal procedures, bureaucratic delays, and civil suits, resulting in the deterioration of the assets' value, thus making it difficult for creditors to enforce their claims (Ahluwalia, 2002). Further, any reorganization plans were also often blocked and vetoed by workers, adding to further delays (Vig, 2013). The corporate bond markets were almost nonexistent, and the lending market was a near-monopoly of public sector financial institutions and banks (Ahluwalia, 2002). These debt recovery problems led to mounting of nonperforming assets (NPAs) level.

Post-liberalization, to bring more competition into the lending markets from private lending institutions, improve operating efficiency and remove the bottlenecks in the debt recovery process, the Indian government enacted the Recovery of Debts Due to Banks and 
Financial Institutions Act (1993) (the RDDB Act). Specialized dedicated debt recovery tribunals (DRTs) were set up by the government under this legislation to recover debts of more than INR one million that were due to banks or financial institutions. DRTs intended to bypass lengthy legal processes for the speedy recovery of debts. However, it was not until 2002 that the Act was finally enforced in a way that was legally compatible with the judicial requirements. DRTs resulted in a significant reduction in the delinquency rates and costs of borrowing (Visaria, 2009).

In the year 2002, retroactive legislation called the Securitization and Reconstruction of Financial Assets and Enforcement of Security Interests Act (The SARFAESI Act) was enacted. ${ }^{4}$ This law allowed creditors to bypass the lengthy court process and seize the defaulting firms. The Act applied only to secured loans and empowered the banks and financial institutions to seize and liquidate the secured assets of a defaulting firm. ${ }^{5}$ SARFAESI's enforcement was delayed until 2004, as the regime was challenged on constitutional grounds. However, the Supreme Court of India upheld the Act's validity.

Vig (2013, p. 888) notes the following: "Before the SARFAESI Act, however, Indian law actually prevented creditors from seizing security at any time-whether before or after insolvency proceedings—without a tribunal order. Recovery of security interests was thus effectively stayed, pending the resolution of these tribunal proceedings, by the lack of extraproceeding mechanisms." Thus, in the pre-SARFAESI Act era, laws in India were pro-debtor, in contrast to some European countries, such as the United Kingdom, France, and Germany, where the law allowed secured creditors to seize and liquidate securities without any delays. While these European countries had pro-creditor regimes, the United States creditor protection laws, though stringent, were pro-debtor, as the main objective of the creditor protection laws

\footnotetext{
${ }^{4}$ The SARFAESI Act was retroactive, i.e., it is applicable to both old as well as new contracts.

${ }^{5} \mathrm{~A}$ default firm is a firm that has not made payments for more than six months.
} 
was to maintain the business as a going concern. Pre-SARFAESI Act regime was similar to that of France, where the primary objective is to safeguard workers' jobs while maintaining business operations (White, 1996). Therefore, the Indian legal environment resembled that of France rather than the United States before the SARFAESI Act (Vig, 2013).

In the post-SARFAESI Act regime, the secured creditor rights were strengthened and the legal system in India transitioned from a pro-debtor regime to a pro-creditor regime. Some of the important provisions under the SARFAESI Act regime, which enabled this transition, include the right of secured creditors to take over the management of the secured assets or the business itself. The secured creditor now has the right to sell off the secured assets to recover the debt obligation after providing a 60-day notice to the defaulting debtors. In the case of legal proceedings, the post-SARFAESI Act regime has shifted the burden of proof from the creditor to the debtor. Thus, in the post-SARFAESI Act era, the Indian creditor's rights protection significantly improved. In our case, this regime shift facilitates the examination of the effect of creditor rights on the corporate borrowing of firms with different access to internal capital.

\section{Related Literature and Hypothesis Development}

The economic power theory of credit suggests that the empowerment of creditors should lead to the expansion of contractual space, as creditors can enforce their rights more easily (Hart and Moore, 1994; Townsend, 1979). Supporting this view, Djankov et al. (2007, p. 300) note: "When lenders can more easily force repayment, grab collateral, or even gain control of the firm, they are more willing to extend credit." This implies that any policy shift that makes it easier for the creditors to recover their financial interest and decreases information asymmetry between firms and creditors should accord greater confidence to the lending fraternity in expanding the contractual space at a lower cost (La Porta et al., 1998). ${ }^{6}$ In other

\footnotetext{
${ }^{6}$ Taluja, Seth and Berger (2017) show that the SARFAESI Act (which provided easier access to collateral) helps in reducing the problem of ex ante information asymmetry.
} 
words, the supply of the lending market should be boosted by such positive changes in regulatory reforms. This supply-side prediction is empirically supported in the literature (Haselmann et al., 2010).

However, there could be a demand-side adaptation induced by the fear among debtors of losing their decision-making flexibility, along with the increased cost of financial distress, including bankruptcy. Such perceived risks may eventually lower the demand for borrowing. Studies attribute this to the generation of high levels of deadweight costs from additional borrowing when creditors impose highly restrictive terms and/or when the associated distress cost, including that of bankruptcy, increases (Aghion et al., 1992; Hart et al., 1997). A number of studies also offer empirical evidence supporting this unintended side effect of restrictive creditor rights (Acharya et al., 2011; Vig, 2013).

Given the inconclusive and mixed evidence on the link between increased creditor rights and firm borrowing, we make a concerted effort to provide some reconciling views and evidence based on firms' access to internal capital. We argue that the inconsistent evidence observed in the literature may be partly explained when we take into account firms' heterogeneity with respect to the degree of constraints they face when accessing their internal capital market.

A number of studies argue that the degree of constraints a firm encounters to access cheaper internal capital that avoids excessive monitoring by external creditors is also dependent on whether a firm belongs to a business group. A business group comprises a set of related firms that have the advantage of accessing each other's resources (resource-based theory), which also creates a significant internal capital market (financial advantage hypothesis). Such advantages arise due to their substantial operational and financial interlinkages and because they are managed by a common group of insiders (Gopalan et al., 2007). For example, drawing on the resource-based theory, Chang and Hong (2000) provide empirical evidence that firms 
belonging to Korean business groups (known as Chaebols in Korea) benefit from the resources owned by other affiliates in the same Chaebols (due to economies of scale and scope). Thus, Chang and Hong (2000) show that internal capital markets within business group firms help to reduce the transaction costs incurred by group affiliates and supplement inefficient external capital markets.

Similarly, testing the financing advantage hypothesis, Khanna and Yafeh (2007) demonstrate that the practice of group affiliated firms replacing expensive external debt with cheap intragroup loans is a remedy for firms funding themselves in underdeveloped capital markets. The financing advantage hypothesis is further supported by Buchuk et al. (2014), whereby they show that the operational performance of Chilean group-affiliated firms that receive intragroup loans increases significantly and their external leverage (external debt over total assets) is approximately $6 \%$ lower, demonstrating strong substitution of external debt by intragroup loans in these firms. As the controlling parent company is an interested party to the intra-loan deal, intragroup loans are considered as soft loans and are easier to negotiate at initiation and further renegotiate at times of financial distress. Such practices may significantly mitigate the default risk, which may ultimately preserve the good reputation of the group (Buchuk et al., 2014). Further, through intragroup lending, the affiliated firms are spared excessive monitoring by external creditors (Lin et al., 2011).

Using Indian firms, Gopalan et al. (2007) empirically demonstrate that a crucial reason that business group firms seek internal financial support from other member affiliates is to avoid spillover reputational damage in case of default by any externally financed member. Gopalan et al. (2007) show that, on average, the intergroup loan flow constitutes $59 \%$ of the operating profits in the year a firm receives loans. Khanna and Palepu (2000), again employing Indian firms, also offer strong evidence that intergroup loans are the channels through which Indian groups transfer cash across member firms. Thus, such a business group structure often 
helps the member group firms to not only overcome the limitations of raising costly external capital but also to avoid the deadweight costs of losing financial flexibility in their decision making (He et al., 2013; Hoshi et al., 1991). The conjecture that firms are less likely to access external finance as a result of having the advantage of operating within the group's internal capital markets is also supported by Shin and Park (1999). Thus, under both the resource-based theory and the financial advantage hypothesis, intergroup lending is a vital source of transferring financial resources across group firms and is generally used to enhance the financial condition of the affiliated but financially weaker firms.

Similarly, the empirical studies also document that compared to their developed counterparts, the cost of raising external capital is generally higher for firms in emerging markets (Wurgler, 2000). Thus, emerging market firms that are part of a business group structure significantly benefit from the relatively cheaper intergroup loans (Gopalan et al., 2007). This benefit of business group firms implies that in the event of any exogenous shift in creditor rights that poses a threat of curbing the flexibility of firms' decision-making power, these firms are in a better position to finance their investment needs from their internal sources. The ability of business group firms to finance their investment needs from their internal sources ensures that they are not exposing themselves to the stricter credit terms and a higher likelihood of financial distress perceived in the new creditor rights regime. As a result, the prediction in these types of group affiliated firms, because of the empowerment in creditor rights, is either no change or a decrease in corporate borrowing. ${ }^{7}$

The expansion of the contractual space and lowered information asymmetry in loan markets, a result of the new creditor protection regime, would see an increase in the supply of the lending offered to unaffiliated standalone and business group firms alike. However, unlike

\footnotetext{
${ }^{7}$ We make an implicit assumption that business group firms do not overleverage or overinvest because of reputational concerns, as there might be spillover effects to the entire group in the event of bankruptcy of any one member of the group. Given the evidence in the current literature, this argument seems to be reasonable (see Gopalan et al., 2007).
} 
group-affiliated firms, the standalone firms do not have the discretion of borrowing from group affiliates. Therefore improved creditor rights regime should lead to an increase in debt financing by the unaffiliated standalone firms.

In the context of India, the introduction of the SARFAESI Act, which is aimed at increasing the secured lending and reducing the cost of debt by strengthening creditor rights protection, positively influenced the supply side. This, however, also had an undesirable impact on the demand for corporate borrowing by curtailing financial flexibility and significantly increasing the deadweight costs in the form of a higher probability of bankruptcy (Vig, 2013). Thus, business group firms that have an alternative channel for funding their investment requirements should, therefore, opt to access the relatively cheaper internal capital, an argument in line with the resource-based theory and the financial advantage hypothesis. This alternative source of funding is, however, not available for the unaffiliated standalone firms, which, therefore, should seek external loans through either secured or unsecured borrowing routes. Based on the above economic arguments, we propose to test the following hypothesis.

$H_{1}$ : Ceteris paribus, following the creditor protection reform (the SARFAESI Act), unaffiliated firms, which have constrained access to internal capital, should borrow more than business group affiliated firms, which have greater access to internal capital.

\section{Data}

We use the Prowess database maintained by the Centre for Monitoring the Indian Economy (CMIE), a private think tank that provides detailed annual financial and other firmspecific data of both listed and unlisted companies. Existing studies including Gopalan et al. (2007), Lilienfeld-Toal et al. (2012) and Vig (2013) extensively make use of this database. Prowess database tracks ownership structures and internal networks of Indian business firms 
and classifies them into business group firms and standalone firms. ${ }^{8}$ For our study, we cover all listed nonfinancial firms available in the database for the sample period of 1996 to 2007. Our final dataset consists of a sample of 43,877 firm-year observations of 5,049 distinct nonfinancial firms listed either on the Bombay Stock Exchange (BSE) or the National Stock Exchange of India Ltd. (NSE) for the sample period. Of these 5,049 sample firms, 1,978 firms belong to 641 unique business groups and 3,071 are unaffiliated standalone firms.

\subsection{Dependent Variable}

In keeping with the existing literature, our dependent variable is firm's borrowing as a proportion of total assets (Total Debt/TA), where Total Debt is total corporate borrowing and $T A$ is the book value of total assets in a firm's balance sheet (La Porta et al., 1998; Vig, 2013). For additional robustness checks, we also use two other sub-categories of corporate borrowing, i.e., the secured borrowing and unsecured borrowing of the firms, as a proportion of total assets. ${ }^{9}$

\subsection{Key Independent Variable}

Our key variable of interest is the interaction of two dummy terms, $C I C_{i}$ and Post $_{t}$. The dummy variable $C I C_{i}$ takes the value of one if a firm $(i)$ is classified as treated firms (unaffiliated standalone firm) or zero for comparison firms (business group affiliated firms). The other dummy variable Post $_{t}$ takes the value of one for year $(t)$ following the SARFAESI Act, i.e., for the years 2002-2007, and zero otherwise. Our key variable of interest is, thus, the

\footnotetext{
${ }^{8}$ Gopalan et al. (2007, p. 763) note the following: "This group affiliation has been previously used in Khanna and Palepu (2000), Bertrand et al. (2002), and other papers. Prowess' classification is based on a continuous monitoring of company announcements and qualitative understanding of group-wise behavior of individual firms and is not solely based on equity ownership. Such broad-based classification, as against a narrow equity-centered classification, is intended to be more representative of group affiliation.".

${ }^{9}$ This subcategorization is an important robustness test, as the SARFAESI Act, by the nature of its provisions, has a direct impact on secured borrowing. It is, therefore, theoretically possible that, given a shock that affects secured borrowing, a firm may reshuffle its debt structure (i.e., lowering its secured borrowing and increasing its unsecured borrowing) without any effect on the overall debt.
} 
DiD estimator $\left[\mathrm{CIC}_{i} \times \mathrm{Post}_{t}\right]$, which captures the causal effect of the SARFAESI Act 2002 on the treated firms that have constrained access to internal capital.

\subsection{Control Variables}

In keeping with the existing literature, we use a number of control variables that may contest our variable of interest (expansion of creditor rights) in explaining the variations in corporate borrowing. Following Whited and Wu (2006), we control for firm size (Size) by taking the natural logarithm of the book value of total assets, where assets are expressed in millions of INR (Indian rupees). We expect Size to be positively related to the amount borrowed, to the extent that it represents a firm's reputation for facilitating greater access to external financing (Fombrun and Shanley, 1990; Shane and Cable, 2002; Williams and Barrett, 2000). We also control for the tangibility of assets (Tangibility) by using the net fixed assets as a proportion of total assets (Rajan and Zingales, 1995) and expect this to be positively related to borrowing as the tangibility of assets represents the firms' collateral capacity to borrow more (Gan, 2007). We further consider the firm-level operating performance (Operating Profitability), measured by earnings before interest, taxes, depreciation, and amortization (EBITDA) scaled by net sales (Vig, 2013). In line with the evidence offered by the existing literature, we expect Operating Profitability to be negatively related to corporate borrowing (Vig, 2013). Our list of control variables also includes the firm's growth potential/valuation as proxied by the market-to-book $(M B)$ value of equity. To the extent that a higher $M B$ represents a firm's reputation, especially in emerging markets (Pinkowitz et al., 2006), and that reputable firms have better access to finance, $M B$ is expected to be positively associated with firm financing.

We also control for the effect of the firm's time-invariant idiosyncrasies by employing firm fixed effects in the regression estimation models. Finally, industry-level shocks, such as 
investment opportunities arising in different industries (sectors) at different times, could confound our estimation (Koirala et al., 2018). We reduce this possibility by employing the interaction of industry and year fixed effects.

\section{Empirical Results}

\subsection{Descriptive Statistics}

Table 1 contains summary statistics for the dependent and control variables for the preSARFAESI Act (1996-2001) and post-SARFAESI Act (2002-2007) periods. Table 1 shows an increase in firms' borrowing as a percentage of total assets, i.e., total borrowing $(38.11 \%$ to $39.07 \%$ ), secured borrowing (32.8\% to $33.01 \%$ ) and unsecured borrowing (8.61\% to $10.19 \%)$, in the post-SARFAESI Act period in comparison to the pre-SARFAESI Act period. Three of the four control variables (Size, Operating Profitability, and $M B$ ) witness a significant increase in the post-SARFAESI Act period, which indicates that firms in the post-SARFAESI Act period experience growth in size growth, operational efficiency, and investment opportunities. We observe a reduction in Tangibility. These changes are consistent with the previous findings (Vig, 2013).

\section{...Table 1 about here...}

Table 2 contains summary statistics for the dependent and control variables for the entire sample period (1996-2007) for the firms classified into unaffiliated standalone firms and business group affiliated firms. A statistically significant difference (at the $1 \%$ significance level) in firms' borrowing, i.e., total borrowing (38.36\% \& 39.49\%) and secured borrowing $(31.88 \% \& 32.50 \%)$, respectively, is observed. Clearly, when we pool the overall sample group, the affiliated firms seem to be significantly higher in terms of total and secured borrowing. This finding is not surprising given the evidence that group affiliated firms are 
greater in size and hold higher levels of tangible assets. The differences in the control variables strongly indicate that group-affiliated firms are typically larger in their capital base (based on Size), have more tangible assets (Tangibility), and exhibit added advantage of the group's reputation when compared to the unaffiliated standalone firms, as reflected in their higher $M B$.

\section{...Table 2 about here...}

\subsection{Analysis of pre-SARFAESI Act Difference in the Trends of the Treated and Comparison}

\section{Firms}

From Table 2, we see that the borrowing by group affiliated firms is significantly higher for the entire sample period (1996-2007). However, these average figures do not reveal changes in the possible trends in the post-reform period relative to the pre-reform period. It is, therefore, important that we analyze whether the treated and comparison firms differ in their corporate borrowing before and after the enforcement of the SARFAESI Act. Further, as the assumption of a parallel trend constitutes a necessary condition to execute shock-based difference-indifferences (DiD) specifications, the trend analysis also allows us to examine if our DiD specification is reliable (Atanasov and Black, 2016).

We present the graphical trend of the total borrowing for the sample of treated and comparison groups for the period of 1998-2005 in Figure 1. This figure presents the yearly rescaled average values of Total Debt/TA for the entire sample period by the treated and comparison firms. For each year, rescaling is performed by deducting the three-year average before the SARFAESI reform (i.e., an average of 1998-2000) from each annual average figure of Total Debt/TA. ${ }^{10}$

\section{...Figure 1 about here...}

\footnotetext{
${ }^{10}$ This rescaling is similar to the spirit of Vig (2013) and Buchuk et al. (2014) which ensures that the beginning of the trend is clustered around the origin, particularly for tractable purposes.
} 
We observe that the treated and comparison firms mostly have similar trends in corporate borrowing before the SARFAESI Act. However, this virtually parallel trend changes for the treated firms following the enforcement of the reform, as they witness a substantial jump in their corporate borrowing in the post-SARFAESI Act period. In contrast, the comparison firms witness a slight drop in their post-SARFAESI Act corporate borrowing. These findings, particularly those related to the business group affiliated firms, are consistent with the previous study that documented the unintended consequences of the creditor reform (Vig, 2013). However, we see that the treated standalone nonaffiliated firms' borrowing increased in the post-reform era. In the following Subsections 5.3 and 5.4, we further test this seemingly differential increase in the borrowing of treated firms in the post-SARFAESI Act period using both univariate DiD and the more robust multivariate DiD specifications.

\subsection{Univariate Difference-in-Differences (DiD)}

We report the univariate DiD estimates of corporate borrowing for the study period of 1996-2007 in Table 3. As shown in column 5, the differences in the mean values of the corporate borrowing of the treated firms before and after the SARFAESI Act in 2002, as represented by total debt, secured debt and unsecured debt as proportions of their total assets, are positive and highly significant. This finding indicates that firms facing greater constraints in accessing internal capital increase their corporate borrowing after the enactment of the SARFAESI Act. The differences in the mean values of the total corporate borrowing for the business group affiliated comparison firms is negative and statistically significant.

\section{...Table 3 about here...}

In terms of economic magnitude, following the SARFAESI Act reform, the Total Debt/TA (Secured Debt/TA) of the treated firms increases, on average, by $2.76 \%$ $(3.66 \%)$ when compared with a decrease by $0.72 \%(0.32 \%)$ for the comparison firms. We also 
observe escalations in Unsecured Debt/TA of $3.54 \%$ and $1.79 \%$ for the treated group and comparison group, respectively. The DiD estimates of the differential borrowing of treated over comparison groups in the post-SARFAESI Act period are positive and statistically significant at the $1 \%$ level. The DiD figures for total, secured and unsecured debt (as \% of the total asset) in Column 7 indicates that compared to the business group affiliated firms, the treated standalone firms increase their borrowing more by $3.48 \%, 3.98 \%$, and $2.75 \%$, respectively.

Taken together, these findings indicate that the strengthening of creditor rights encourages greater corporate borrowing for treated firms, which experience higher levels of constraints to accessing internal capital, relative to the business group affiliated firms (comparison), which face lower levels of constraints to accessing internal capital.

\subsection{Baseline Multivariate Results}

While the univariate DiD examination can provide credible clues, these alone are typically insufficient to determine the causes of the changes in borrowing, particularly in the absence of other control factors. In this subsection, we employ the multivariate regressionbased DiD to estimate the causal effect. To do so, we run the general regression specification (1) to estimate the causal effect using the sample of the treated firms (unaffiliated standalone firms, which have constrained access to internal capital) and comparison firms (business group firms, which have higher access to internal capital).

$$
\begin{aligned}
(\text { Total Debt } / \text { TA })_{i t}= & \alpha+\beta \cdot\left[\text { CIC }_{i} \times \text { Post }_{t}\right]+\boldsymbol{X}_{i t} \cdot \boldsymbol{\delta}+\left[\boldsymbol{X}_{i t} \times \text { Post }_{t}\right] \cdot \boldsymbol{\vartheta}+\left[\boldsymbol{X}_{i t} \times C I C_{i}\right] . \boldsymbol{\rho}+ \\
& \gamma_{i}+\left[\eta_{j} \times \tau_{t}\right]+e_{i t}
\end{aligned}
$$

where $(\text { Total Debt/TA })_{i t}$ is the dependent variable defined as the proportion of total debt to book value of total assets ( $i$ denotes the firm and $t$ denotes the year). Post $t_{t}$ is a categorical variable that takes the value of one for the post-SARFAESI Act period and zero otherwise. $C I C_{i}$ is an indicator variable that takes the value of one for firms that have constrained access 
to internal capital, and zero otherwise. $\boldsymbol{X}_{\boldsymbol{i t}}$ is a vector of the key control variables, as defined in Subsection 4.3. $\gamma_{i}, \eta_{j}$ and $\tau_{t}$ are the firm, industry and time fixed effects respectively. $e_{i t}$ is the error term. $\beta$ is the regression coefficient of our key variable, i.e., the interaction term of Post $_{t}$ and $C I C_{i}$, i.e., of the DiD variable $\left[\mathrm{CIC}_{i} \times\right.$ Post $\left._{t}\right]$. Standard errors are clustered at the firm level. To remove the effect of obvious outliers, the variables are winsorized at the top and bottom $1 \%$ in all the regression models.

Three important features of the estimation specification (1) are worth noting. First, the vector of the interaction term $\left[\boldsymbol{X}_{i t} \times\right.$ Post $\left._{t}\right]$ controls for the change in (Total Debt/TA $)_{i t}$ as a result of the change in firm fundamentals in the post-SARFAESI Act period. Second, the vector of the interaction term $\left[\boldsymbol{X}_{i t} \times C I C_{i}\right]$ controls for differences in the evolution of the firm characteristics of the treated and comparison firms. Third, the interaction term $\left[\eta_{j} \times \tau_{t}\right]$ controls for the change in (Total Debt/TA $)_{i t}$ as a result of industry-specific shocks arising at different times (see Vig, 2013). We use the Prowess industry classification which is comparable to the SIC codes used in other popular databases such as Thomson Reuters Datastream. The Prowess industry codes are 15 digit codes with 192 unique industry groups. Excluding the financial sector gives us 138 unique Prowess industry codes for our sample firms. In the spirit of Vig (2013) and Gopalan et al. (2007), we use the first seven digits, which yields 23 unique nonfinancial industry-clusters. ${ }^{11}$ We report the DiD regression results of different variants of specification (1) in Table 4.

\section{...Table 4 about here...}

The regression estimates, as reported in models [1] to [5], are for the entire sample period of 1996-2007. As a shock-based empirical analysis with a longer study period may introduce additional noise to causal inferences (Koirala et al., 2018), we undertake a multivariate analysis

\footnotetext{
${ }^{11}$ See appendix Table A1 for Prowess industry classification used in this study.
} 
of specification (1) for the narrower period of 1998-2005 and report the findings in models [6] to [10]. For both study periods, we start by estimating the coefficients from specification (1) using entire set of observations without including the control variables in models [1] and [6]. To gauge the sensitivity of our results, driven by the missing data on the control variables, models [2] and [7] estimate the DiD without controls for those observations for which we have non-missing control variables. We introduce control variables in the remaining models.

As observed in Table 4, the DiD coefficients are positive and highly significant at the 1\% significance level for models [1] to [4] and [6] to [9], which indicates consistency in the results for both the study periods. In terms of the economic magnitude across all models, the expansion of creditor rights seems to have increased the corporate borrowing of firms that have constrained access to internal capital, on average, in the range of $2 \%$ to $4 \%$. These results support the view that firms with constrained access to internal capital borrow more in comparison to those with higher access to internal capital. While we report standard errors clustered at the firm-level in all our regression specifications throughout the text, the results are robust to the clustering of standard errors at the business group level, which we report for the main regression in Appendix Table A2.

We further test our argument with an alternative dependent variable, i.e., Debt-Growth, which is computed as $\left(T D_{-} G r o w t h\right)_{i t}=\left(\Delta\right.$ Total Debt $_{t, t-1} /$ Total Debt $\left._{t-1}\right)$ in models [5] and [10] of Table 4. The results reveal an increase in the annual average debt-growth for treated firms by $4.7 \%$ and $7.4 \%$ for the $1996-2007$ and $1998-2005$ study periods, respectively.

In terms of the controls, almost all the variables carry the expected signs and are statistically significant, which is consistent with the findings of Vig (2013). The coefficients of the interaction term of the post-reform dummy and firm characteristics reveal that firms with higher MB, Tangibility, and Operating Profitability are associated with lower corporate borrowing in the post-SARFAESI Act period, which is consistent with previous studies on the 
unintended consequences of the SARFAESI Act (Vig, 2013). ${ }^{12}$ In summary, the results in Table 4 highlight the positive effect of creditor protection on corporate borrowing for firms having constrained access to internal capital.

\subsection{Further Robustness Checks}

In the following Subsections 5.5.1 to 5.5.4, we perform a number of checks to ensure the robustness of our baseline regression results, as reported in Table 4.

\subsubsection{Placebo Tests}

It is important to rule out the possibility that other confounding economic events surrounding the reform shock (i.e., those which might have occurred in the years before the SARFAESI Act enforcement) maybe driving our results. To check these possibilities, we undertake Placebo tests by estimating the following general regression specification (2):

$$
\begin{gathered}
(\text { Total Debt } / T A)_{i t}=\alpha+\beta_{1} \cdot\left[A F Y_{[-1]} \times C I C_{i}\right]+\beta_{2} \cdot\left[A F Y_{[-2]} \times C I C_{i}\right]+\beta_{3} \cdot\left[A F Y_{[-3]} \times\right. \\
\left.C I C_{i}\right]+\boldsymbol{X}_{i t} \cdot \boldsymbol{\delta}+\left[\boldsymbol{X}_{i t} \times C I C_{i}\right] \cdot \boldsymbol{\rho}+\gamma_{i}+\left[\eta_{j} \times \tau_{t}\right]+e_{i t}
\end{gathered}
$$

where after false shock year $\left(A F Y_{[-t]}\right)$ is a categorical variable that takes the value of one for years following and including the false shock year $\left(F S Y_{[-t]}\right)$, and zero otherwise. Our placebo experiment uses three different false shock years, i.e., one year $\left[F S Y_{[-1]}\right]$, two years $\left[F S Y_{[-2]}\right]$, and three years $\left[F S Y_{[-3]}\right]$ before the true creditor protection reform in 2002 . We limit our study period to 2001 to prevent the effect of true reform on our estimates of placebo-experiment. All the other variables in the specification (2) are as defined in Subsection 5.4. A significant DiD coefficient of either of the interaction terms $\left[A F Y_{[-1]} \times C I C_{i}\right],\left[A F Y_{[-2]} \times C I C_{i}\right]$ or $\left[A F Y_{[-3]} \times C I C_{i}\right]$ of this placebo-design would undermine the causal effect documented in

\footnotetext{
${ }^{12}$ We present an alternative DiD specification with treated (control) firms comprised of firms belonging to the upper (lower) tercile on the basis of a 3-year average of the pre-treatment asset tangibility in Table A3 of the appendix. The results are qualitatively consistent with the findings of Vig (2013).
} 
Tables 3 and 4, as it opens the possibility that the results are affected by the lead effects of other confounding shocks closer to the SARFAESI Act reform. The results of different variants of specification (2) are presented in Table 5.

\section{...Table 5 about here...}

As observed in Table 5, the DiD coefficients with FSYs are not significant, either individually in models [1] to [3] or jointly in the model [4]. These results rule out the possibility of any lead effect of other confounding shocks and are, hence, consistent with the key results presented in Tables 3 and 4. Additionally, the insignificant DiD of the placebo design formally establishes no systematic difference in the variable of Total Debt/TA exists between the treated and comparison firms before the treatment of the creditor protection shock after controlling for firm characteristics. ${ }^{13}$

\subsubsection{Alternative Measures of Corporate Borrowing and Shorter Period Analysis}

While the SARFAESI Act provisions are aimed at protecting only the secured creditors and increasing the total secured borrowing, the law may also have resulted in a spillover effect in the unsecured debt market, which is potentially a result of the reduced cost of debt. For example, Vig (2013) provides evidence of the reduced cost of debt in the post period of the SARFAESI Act. Further, it may be the case that due to the more stringent and costly provisions of the SARFAESI Act and the overall reduced cost of debt, firms access the unsecured debt market more than the secured debt market. This possibility motivates us to perform robustness checks using secured and unsecured corporate borrowing scaled by the book value of total

\footnotetext{
${ }^{13}$ As there could be an anticipation of legal reforms, given the fact that a law takes some time from initiation to enforcement, the insignificant placebo could mean that firms may be hesitant to act on the reform stimuli, given the higher noise and uncertainty surrounding their implementation. In the event that a firm decides to act ex ante on an anticipated reform cue, the causal effect could be underestimated (Dharmapala and Khanna, 2013).
} 
assets as our dependent variable. We present the DiD regression results for both secured and unsecured corporate borrowing in models [1] to [12] of Table 6.

\section{...Table 6 about here...}

We run the regressions for two periods, as noted in subsection 5.4, for both these forms of borrowing. The regression estimates of models [1], [4], [7] and [8] are without any control variables, whereas the regression estimates of models [2], [5], [8] and [11] are for the subsample of firms with non-missing control variables. We allow for control variables in the remaining models. While the longer period may be important to evaluate the persistent effect of the reform, the shorter-term period analysis provides a cleaner effect, as it reduces the effects of other confounding events that are associated with a research design within a wider study period. For both secured and unsecured borrowing, we report the results of the shorter period of 1998-2005 in models [4] to [6] and [10] to [12], while models [1] to [3] and [7] to [9] of Table 6 are for the entire study period of 1996-2007.

In line with our main findings of Table 4, in the post-SARFAESI Act period, both secured and unsecured corporate borrowing increase significantly (at the $1 \%$ significance level) among the treated firms, relative to the comparison groups. These findings confirm the conjecture that strengthening creditor rights encourages corporate borrowing by firms with constrained access to internal capital.

\subsubsection{Alternative Measure of a Firm's Access to Internal Capital}

Our main empirical estimation, discussed in Section 5.4, assumes that compared to their business affiliate peers, standalone firms have constrained access to internal capital, as extensively argued and empirically shown by the existing literature. This distinction is arguably vivid, as it tracks the firm's connectedness with other business units within a business group to pool resources in the event of capital shock (Gopalan et al., 2007). We now relax this distinction 
of internal capital constraints to allow firms that could generate and accumulate internal substitute capital to meet their capital demands internally. For example, a growing body of literature shows that firms prefer internal financing sources over external capital due to the higher cost and loss of decision making flexibility associated with external financing (Donaldson, 1961; Leary and Roberts, 2005; Myers, 2003; Myers and Majluf, 1984; Zeidan et al., 2018). Using the tax wedge theory, Becker et al. (2013) show that firms prefer investments using retained earnings (internal equity), as internal equity is cheaper than external equity (share issues). Similarly, Hubbard and Palia (1999) use an average two-year dividend pay-out ratio as one of the measures for identifying the financially unconstrained firms and those that face costly external financing.

In keeping with the literature, we employ a proxy that reflects the firms' internal capital generation capacity, known as the Internal Capital Generation Rate (ICGR). Following Fabozzi and Markowitz (2011), we measure ICGR as a product of the plowback ratio (retention ratio) and return on equity (ROE), as given in specification (3). All else equal, a lower ICGR implies higher constraint to internal capital.

$$
\mathrm{ICGR}=R O E \times(1-\text { dividend payout ratio })
$$

We test our key hypothesis using the following DiD regression specification (4):

$$
\begin{gathered}
\left(\text { Debt }_{T} \text { TA }\right)_{i t}=\alpha+\beta \cdot\left[\text { LowIC }_{i} \times \text { Post }_{t}\right]+\boldsymbol{X}_{i t} \cdot \boldsymbol{\delta}+\left[\boldsymbol{X}_{i t} \times \text { Post }_{t}\right] \cdot \boldsymbol{\vartheta}+ \\
{\left[\boldsymbol{X}_{i t} \times \text { LowIC }_{i}\right] \cdot \boldsymbol{\rho}+\gamma_{i}+\left[\eta_{j} \times \tau_{t}\right]+e_{i t},}
\end{gathered}
$$

where $(\operatorname{Debt} / \mathrm{TA})_{i t}$ is either Total debt/TA, Secured debt/TA or Unsecured debt/TA. ${ }_{L o w I C}$ is a categorical variable that takes a value of one for the firms falling in the lower tercile based on firms' three-year average of ICGR before the SARFAESI Act, i.e., from 1999 to 2001, and zero for the firms falling within the upper tercile. The treated firms are those with the lowest level of ICGR, and the comparison firms are those with the highest level of ICGR. 
Post $_{t}$ is a categorical variable that takes the value of one for the years following and including the year of introduction of the SARFAESI Act, i.e., 2002, and zero otherwise. The other variables are as defined in Subsection 5.4. The results of specification (4) are presented in Table 7.

\section{...Table 7 about here...}

For each dependent variable $(D e b t / T A)_{i t}$, i.e., Total debt/TA, Secured debt/TA and Unsecured debt/TA, models [1], [3] and [5] of Table 7 report the DiD coefficients without control variables, and models [2], [4] and [6] include additional firm controls. As reported in models [1] to [4], we find that the DiD coefficients are highly significant and positive at the $1 \%$ significance level for the total borrowing and secured borrowing variables and are positively significant at $5 \%$ for the unsecured borrowing variable in the model [5]. In terms of the economic magnitude, the strengthening of creditor rights relatively increases the total corporate borrowing (secured borrowing) of firms that have constrained access to internal capital (firms in lower tercile) in the range of $7.7 \%-9.6 \%$ $(7.2 \%-8.1 \%)$ of total assets more than their less constrained peers (firms in upper tercile). The effect is insignificant for unsecured borrowing after attributing to firm characteristics (model [6]). In terms of controls, all the variables carry the expected signs and consistent with the findings of Vig (2013).

We further employ triple differences (DiDiD) regression to gauge the differential effects of creditor rights expansion on standalone firms with constrained access to internal capital. The fact that business group firms can exercise their connectedness to pooled resources when needed means that the reliance on internally accumulated capital should be more relevant for standalone firms (Gopalan et al., 2007). Thus, we predict the creditor rights reform shock should have a positive borrowing effect on standalone firms that have higher constraints to 
access internal capital and have a lower level of ICGR. To test this prediction, we employ a DiDiD, as noted in the following general regression specification (5).

$$
\begin{gathered}
\left(\frac{\text { Debt } \left._{T A}\right)_{i t}=\alpha+\omega .}{}\left[\text { CIC }_{i} \times \text { Post }_{t} \times \text { Low IC }_{i}\right]+\beta \cdot\left[\text { CIC }_{i} \times \text { Post }_{t}\right]+\lambda .\left[\text { Low IC }_{i} \times \text { Post }_{t}\right]+\right. \\
\boldsymbol{X}_{i t} \cdot \boldsymbol{\delta}+\left[\boldsymbol{X}_{i t} \times \text { Post }_{t}\right] \cdot \boldsymbol{\vartheta}+\left[\boldsymbol{X}_{i t} \times \text { Low IC } i\right] \cdot \boldsymbol{\rho}+\gamma_{i}+\left[\eta_{j} \times \tau_{t}\right]+e_{i t},
\end{gathered}
$$

The coefficient $\omega$ of the triple interaction term $\left[\right.$ CIC $_{i} \times$ Post $_{t} \times$ LowIC $\left._{i}\right]$ measures the marginal effect of the SARFAESI Act reform on the corporate borrowing of standalone firms with lower ICGR, relative to the other business group affiliated firms with higher levels of ICGR. The interaction term $\left[\right.$ CIC $_{i} \times$ Post $\left._{t}\right]$ gauges the differential effect of SARFAESI Act reform on borrowing between unaffiliated standalone and business group affiliated firms. Similarly the interaction term $\left[\right.$ Low IC $_{i} \times$ Post $\left._{t}\right]$ measures the differential effect of SARFAESI Act reform on borrowing between firms with low and high internal capital generation. All other variables are defined as per specification (4). The outputs of the estimations of the different variants of specification (5) are presented in Table 8.

\section{...Table 8 about here...}

Models [1], [3] and [5] of Table 8 report the DiDiD coefficients with fixed effects; models [2], [4] and [6] include additional firm controls. As reported in models [1] to [4], we find that the DiDiD coefficients are positive and statistically significant, indicating an increase in the total and secured corporate borrowing of firms that have constrained access to internal capital (treated firms having low ICGR). The magnitude of the coefficients is in the range of 2.6\% (model [1] for total borrowing scaled by total assets) to 3.7\% (model [3] for secured borrowing scaled by total assets) after the expansion of creditor rights. In terms of the controls, all the variables carry the expected signs and are statistically significant, which is consistent with the previous results. 
Taken together, the results presented in Tables 7 and 8 indicate that the firms with lower levels of ICGR or that have otherwise constrained access to internal capital, increase their borrowing relatively more following the SARFAESI Act. This finding again highlights the positive effect of the creditor protection reform on corporate borrowing when firms have constrained access to internal capital.

\subsubsection{Propensity Score Matched Difference-in-Differences (PSM-DiD)}

Our main estimation model is accommodative of the differences among the treated and comparison groups, which may raise the concern of comparability between the two groups. In this section, we take a further step to reduce the possibility that our results could be driven by differences in firms' fundamentals between the treated and comparison groups. Here, we employ the DiD regression between the propensity score matched highly comparable treated and comparison groups. ${ }^{14}$ The results of the different estimations related to PSM-DiD are presented in Table 9.

\section{...Table 9 about here...}

We first estimate the pre-SARFAESI Act probit model to measure the likelihood of being included in a treated or comparison group based on the following regression specification:

$$
C I C_{i}=\alpha+\boldsymbol{X}_{i t} \cdot \boldsymbol{\beta}+\eta_{j}+e_{i t}
$$

where $C I C_{i}$ takes the value of one for unaffiliated standalone firms that have constrained access to internal capital, and zero otherwise. $\boldsymbol{X}_{\boldsymbol{i t}}$ is the vector of the control variables defined in Section 4.3, and $\eta_{j}$ controls for industry fixed effects. By applying propensity matching without

\footnotetext{
${ }^{14}$ Even though we have shown in Section 5.2 that our treated and comparison group firms meet the preSARFAESI Act parallel trend assumption, these firms still differ in their firm fundamentals, as presented in Table 2. The triangulation of our causal inference with PSM-DiD, therefore, has merit.
} 
replacement based on the propensity score between treated-comparison pairs for all the covariates, we identify 719 pairs of matched treated and comparison group firms. We present the results of specification (6) for the entire sample and the matched subsample in columns 1 and 2, respectively, of Panel A of Table 9. We observe that the explanatory power of specification (6) is reduced from pseudo- $\mathrm{R}^{2}=0.239$ in column 1 for the entire sample to pseudo- $\mathrm{R}^{2}=0.001$ in column 2 for the matched treated and comparison groups. This finding indicates that the matched treated and comparison groups are not systematically different in terms of their firm fundamentals. We further present the pre-SARFAESI Act difference between firm controls in Panel B of Table 9, which clearly shows that the matched 719 pairs of treated and comparison firms have similar and comparable firm fundamentals before the SARFAESI Act.

To assess how the SARFAESI Act reform has affected the treated and comparison firms, we present a time series plot of rescaled values (similar to Figure 1) of the corporate borrowing of the matched firms from 1998 to 2005 in Figure 2. We find that there is no difference in the trend of corporate borrowing prior to the SARFAESI Act. However, following the SARFAESI Act reform, the corporate borrowing of treated firms has a positive trend compared to a marginal decline in the borrowing of the group affiliated firms, which further confirms the positive effect of the expansion of creditor rights on the corporate borrowing of firms with constrained access to internal capital. ${ }^{15}$

\section{...Figure 2 about here...}

\footnotetext{
${ }^{15}$ We obtain a similar graph when we plot the time series of secured debt (Secured Debt/TA $)_{i t}$. However, we only present the time series plot of (Total Debt/TA) ${ }_{i t}$ for brevity.
} 
We supplement our suggested findings from the time series plot with multivariate DiD estimation. We present a PSM-DiD regression for the matched pairs of treated and comparison groups in Panel C of Table 9 using the following general specification (7).

$$
(\operatorname{Debt} / \mathrm{TA})_{i t}=\alpha+\beta \cdot\left[\text { CIC }_{i} \times \text { Post }_{t}\right]+\boldsymbol{X}_{\boldsymbol{i t}} \cdot \boldsymbol{\delta}+\gamma_{i}+\left[\eta_{j} \times \tau_{t}\right]+e_{i t}
$$

where $(\text { Debt/TA })_{i t}$ is either Total debt/TA or Secured debt/TA. All the other variables are as defined in Section 5.4. We see that the DiD coefficient is significantly positive for the subsample of highly comparable treated and comparison group firms, which is consistent with our main results. In terms of the economic magnitude, the matched treated firms increase their total corporate borrowing by $2.8 \%$ to $2.9 \%$ (models [1] and [2] of panel C) and secured borrowing by $2.4 \%$ to $2.6 \%$ (models [3] and [4] of panel C) following the SARFAESI Act reform. Our supplementary results of the univariate DiD analysis in Panel D further support the findings from the multivariate DiD analysis presented in Panel C. We find that the total borrowing and secured borrowing, both scaled by total assets, differentially increase by $2.59 \%$ and $2.83 \%$, respectively, for the treated firms in the post-SARFAESI Act period.

\subsection{Effect of Creditor Protection on Private (non-listed) Firms}

The argument of the positive effect of creditor protection on the corporate borrowing of the firms that are constrained to internal capital should be more pronounced for private firms, which are presumably more constrained to internal capital than their listed counterparts. However, following similar arguments to those presented in Section 3, private firms that belong to a business group can be considered less constrained, as they can pool resources from the group in the face of a creditor protection shock. In this section, we extend our empirical test designed in the specification (1) to the sample of private unlisted Indian firms. For the analysis, the treated firms are private unaffiliated standalone firms and the comparison firms are private 
firms affiliated to a business group. We collected 32,288 firm-year observations from 8,807 unique private non-listed Indian firms with 6,705 standalone private firms and 2,102 affiliated group firms. We gauge the growth opportunities for this sample of firms by their sales growth. The DiD regression results are reported in Table 10.

\section{...Table 10 about here...}

As reported in models [1] to [4] of Table 10, the total debt and secured debt of the unaffiliated private firms significantly increase in the range of $3 \%$ to $4.3 \%$ compared to their group-affiliated peers. Models [5] and [6] show a significant reduction, in the range of $-2.4 \%$ to $-2.6 \%$, in the unsecured borrowing of treated firms. To the extent that secured debt is cheaper compared to unsecured forms of credit, an implication of the result could be the partial substitution of a costlier financing source by a cheaper source. ${ }^{16}$ Alternatively, following the collateral-based creditor protection reform, the unsecured debt market could become a viable alternative for the group affiliated firms who could lower their secured debt and substitute it with the unsecured debt, thus making it more difficult for the otherwise standalone firms to access this market segment.

\subsection{Heterogeneity within the Business Group}

In this section, we explore two important sources of heterogeneity within business group firms that may affect corporate borrowing differentially. The first source emerges from the affiliation with a financial institution within the business group and the second is related to the net borrowing or lending status of a member firm within the business group.

\footnotetext{
${ }^{16} \mathrm{Vig}(2013)$ documents a decrease in the cost of debt after the SARFAESI Act regime.
} 


\subsubsection{Financial Institution as an Affiliated Member}

Having a financial institution as an affiliated member could be an important source of heterogeneity within business group firms that may moderate the link between creditor rights protection and debt financing. It could be argued that business group firms with no affiliated financial institution could be more constrained vis-à-vis their access to internal finance relative to firms that do have a financial institution as an affiliated member. This implies that, in our empirical set-up, business group affiliated firms with no affiliated financial institution and in the post creditor protection reform period of 2002 should increase their borrowing more relative to that of business group firms that have an affiliated financial institution.

We test this conjecture by examining the subsample of our data that includes only business group affiliated firms. By mapping each firm with all other firms within a business group from the universe of financial and nonfinancial firms in our database, we identify 416 (3,895 firm-year observations) distinct business group firms without any affiliated financial institution in their group (treated firms) and 1,562 (11,233 firm-year observations) distinct business peers with at least one affiliated financial institution in their group (comparison firms). We run the following $\mathrm{DiD}$ specification (8) with these alternative groups of treated and comparison firms using the subsample dataset of business firms.

$$
\begin{aligned}
& \left(\text { Debt }_{\text {TA A }}\right)_{i t}=\alpha+\beta .\left[\text { NonFinConnect }_{i} \times \text { Post }_{t}\right]+\boldsymbol{X}_{\boldsymbol{i t}} \cdot \boldsymbol{\delta}+\left[\boldsymbol{X}_{\boldsymbol{i t}} \times \text { Post }_{t}\right] \cdot \boldsymbol{\vartheta}+ \\
& {\left[\boldsymbol{X}_{i t} \times \text { NonFinConnect }_{i}\right] \cdot \boldsymbol{\rho}+\gamma_{i}+\left[\eta_{j} \times \tau_{t}\right]+e_{i t}}
\end{aligned}
$$

where $(D e b t / T A)_{i t}$ is either Total debt/TA, Secured debt/TA or Unsecured debt/TA. NonFinConnect $_{i}$ is an indicator variable that takes the value of one for business group firms with no affiliated financial institution (treated firms), and zero for those business group firms with an affiliated financial institution (comparison firms). All the other variables are as defined in Subsection 5.4. The results of the estimations are reported in Table 11. 


\section{...Table 11 about here...}

In Table 11, we observe that the increase in total corporate borrowing is in the range of $3.33 \%$ to $4.28 \%$ (Models [1] and [2]) and secured borrowing in the range of $2.82 \%$ to $3.64 \%$ (Models [3] and [4]) for more financially constrained business firms with no affiliated financial institution when compared to their business group counterparts with an affiliated financial institution. However, there seems to be no differential change in the unsecured category of borrowing. ${ }^{17}$ The findings, generally, further lend support to the view that creditor protection reforms increase corporate borrowing more for firms that are relatively more constrained to their access to internal capital.

\subsubsection{Net Receivers or Suppliers of Debt within the Group}

Intragroup borrowing or lending may be important for business group member firms to avoid default (Gopalan et al., 2007) or attain investment efficiency (Buchuk et al., 2014). However, it may be plausible that compared to their peers that are net suppliers of intragroup loans, net borrower affiliates would respond to a creditor protection reform differently. In this subsection, we exploit the heterogeneity within business group firms based on whether a firm is a net-borrower or net-supplier of the intragroup financing. For group-affiliated firms, the Prowess database reports intragroup lending and intragroup borrowing. Using these data-points for each firm-year observation, we define a group affiliate as a Supplier (Receiver) of intra group loans and advances if the difference between total intragroup lending and total intragroup borrowing of a firm is positive (negative) for that year. We identify 4,504 firm-year observations of 1,709 unique supplier-firms of intragroup loans and advances, and 1,924 firm-

\footnotetext{
17 This is potentially due to the fact that the SARFAESI Act specifically targeted the secured debt market, and thus, within this subgroup of business firms, no differential changes in unsecured debt is not a surprising finding.
} 
year observations of 1,100 unique receiver-firms for our study period (1996-2007). We report the univariate analysis of corporate borrowing in Table $12 .{ }^{18}$

\section{...Table 12 about here...}

Table 12 reveals that, compared to the net-supplier firms, which do not change their secured debt borrowing, the net receiver firms (net debtor) lower their secured debt by $3.56 \%$ (significant at $1 \%$ ) in the post-SARFAESI Act regime. The results imply that firms with greater access to internal capital (net-receiving firms in this case) could adapt to substitute external borrowing with internal borrowing when facing threats from stronger creditor protection reforms. Similarly, both receiving and supplying firms increase their unsecured borrowing in the post-SARFAESI Act period. ${ }^{19}$

\subsection{Implications}

In this subsection, we examine the implications of increased corporate borrowing by the treated firms in the post-SARFAESI Act reform period. We investigate the effect by employing three implication variables as the dependent variables, i.e., Capital Expenditure (Capex), Return on Assets $(R O A)$ and proxy of firm valuation $(M B)$. Extant literature suggests that greater access to finance should affect real investments positively (Almeida et al., 2017; Campello et al., 2010). Therefore, an improvement in financial access should improve Capex. For a year $t$, we calculate Capex for a firm $i$ as an addition to fixed assets scaled by the book value of total assets. Similarly, we expect an improvement in financial access should lead to improved operational performance, as studies show that greater access to finance encourages

\footnotetext{
${ }^{18}$ Due to significant missing observations in this particular dataset on intragroup lending/borrowing, we discuss the heterogeneity on the basis of univariate analysis, as the efficiency of the regression estimations is highly compromised in the regression framework.

${ }^{19}$ Due to missing data, the sum of secured and unsecured borrowing may not be equal to total borrowing. While the data on intragroup borrowing suffer from missing data problems, the finding is consistent with the argument that unconstrained firms substitute their borrowing to adapt to the threat that a group firm may face due to creditor protection.
} 
profitable investments (Boubakri and Cosset, 1998; King and Levine, 1993). We, therefore, gauge operational performance using $R O A$, which is computed as earnings before interest and taxes $(E B I T)$ scaled by the book value of total assets.

Finally, our third implication variable is a market-based measure of firm performance, i.e., market valuation. To the extent that market values improve access to finance (La Porta et al., 2002), we expect improved access to corporate borrowing would lead to higher equity valuations. We compute equity valuation by employing $M B$, as defined earlier. To estimate the effect of increased corporate borrowing on the implication variables, we employ the following estimation specification:

$$
\begin{gathered}
\text { Implication }_{i, t+1}=\alpha+\beta \cdot\left[\text { CIC }_{i} \times \text { Post }_{t}\right]+\boldsymbol{X}_{i \boldsymbol{t}} \cdot \boldsymbol{\delta}+\left[\boldsymbol{X}_{i t} \times \text { Post }_{t}\right] \cdot \boldsymbol{\vartheta}+\left[\boldsymbol{X}_{\boldsymbol{i t}} \times C I C_{i}\right] \cdot \boldsymbol{\rho}+ \\
\gamma_{i}+\left[\eta_{j} \times \tau_{t}\right]+e_{i t}
\end{gathered}
$$

where the Implication variables are in the lead-year, i.e., $t+1$. We control for firm Size, and Tangibility, as time-varying differences among these firms' fundamentals could affect the implication variables (Koirala et al., 2018). ${ }^{20}$ All the other variables in the specification (9) are as defined in Section 5.4. The results of the implication regressions are presented in Table $13 .{ }^{21}$

\section{...Table 13 about here...}

We see in Model [1] that the treated firms increase their Capex significantly in the lead years by $2.4 \%$, thus indicating a positive effect of increased borrowing on real investment.

\footnotetext{
${ }^{20}$ As one of the implication variables, $M B$, is also the control variable for the main estimation model in specification (1), there may arise an obvious concern of a circular loop of regression by swapping the variable position from the right-hand side to the left-hand side of the estimation model. However, $M B$, when used as an implication variable, is expressed in the lead period $(\mathrm{t}+1)$ form, whereas $M B$, when used as one of the control variables in specification (1), is in a level period form. MB-lead in specification (9), as a dependent variable, would account for change in a firm's valuation following the improved access to finance of the previously constrained firms. However, we obtain qualitatively similar results (not reported in the text) when we replace $M B$ by Tobin's $Q$ as an alternative measure of firm valuation.

${ }^{21}$ The results are consistent when we use a 2 -year average of the implication variables in the lead-time, i.e., Implication $_{i,([t+1]+[t+2]) / 2}$.
} 
Similarly, Model [2] shows that the treated firms improve their operating performance significantly by $1.3 \%$ in the years following their expansion of corporate borrowing, indicating a positive effect on firms' operational performance gauged by RoA. Finally, the model [3] indicates that the treated firms experience higher market valuation in the subsequent years, which indicates that the improved corporate borrowing of treated firms also helps improve their market performance in the following years. Similarly, higher operating performance and valuation accompanying higher capital investments by the standalone firms in the postSARFAESI Act reform period indicate the positive effects of creditor protection on investment efficiency (Buchuk et al., 2014).

These results presented in this section, which show that the treated firms subsequently invest more, perform better and are valued higher than the non-treated firms, also lend support to the argument that the expansion of creditor rights improves the allocative efficiency by directing capital towards the needy, otherwise constrained, standalone firms in an economy (Almeida and Wolfenzon, 2006). To summarize, the strengthening of creditor rights causes positive investment, performance, and valuation consequences for firms that have constrained access to internal capital.

\section{Conclusion}

The existing literature offers contrasting theoretical perspectives and empirical evidence on the impact of creditor protection on firm borrowing. While one school of thought states that creditor protection should lead to increased firm borrowing, the other takes a contrasting view that such reform may have unintended consequences as creditors become more powerful due to their ability to enforce debt collection, and this may discourage borrowing. Both of these theoretical views are supported by empirical evidence. In this study, we strive to partially

resolve this theoretical and empirical tension by linking these contrasting results to a strand of literature that explores the association between business group affiliation and access to internal 
capital. Specifically, we argue that firms' heterogeneity related to different levels of access to internal capital may explain the link between creditor protection and firm borrowing.

We test our view in a quasi-natural empirical setting by exploiting the enactment of reform, called the SARFAESI Act, which strengthened the rights of creditors in India, where the legal system transitioned from a pro-debtor regime to a pro-creditor regime. Further, we use the business group affiliation literature as our basis to separate firms with varying degrees of constraints to internal capital into treated (standalone firms, which have lower access to internal capital) and comparison groups (business group affiliated firms, which have higher access to internal capital). The findings of our results, supported by extensive robustness checks, offer strong evidence in support of the argument that in the post creditor protection reform regime, firms having constrained access to internal capital borrow more relative to firms that have higher access to internal capital. Thus, the results of our study imply that whether firms increase or decrease borrowing following creditor protection depends on the extent to which firms have constrained access to internal finance. 


\section{References}

Acharya, V. V., Amihud, Y., Litov, L., 2011. Creditor rights and corporate risk-taking. J. financ. econ. 102, 150-166. https://doi.org/10.1016/j.jfineco.2011.04.001

Aghion, P., Hart, O., Moore, J., 1992. The Economics of Bankruptcy Reform. J. Law, Econ. Organ. 8, 523-546.

Ahluwalia, M.S., 2002. Economic Reforms in India Since 1991: Has Gradualism Worked? J. Econ. Perspect. 16, 67-88. https://doi.org/10.1257/089533002760278721

Almeida, H., Wolfenzon, D., 2006. Should business groups be dismantled? The equilibrium costs of efficient internal capital markets. J. financ. econ. 79, 99-144.

Atanasov, V.A., Black, B.S., 2016. Shock-Based Causal Inference in Corporate Finance and Accounting Research. Crit. Financ. Rev. 5, 207-304.

Becker, B., Jacob, Marcus, Jacob, Martin, 2013. Payout taxes and the allocation of investment. J. financ. econ. 107, 1-24. https://doi.org/10.1016/J.JFINECO.2012.08.003

Bertrand, M., Mehta, P., Mullainathan, S., 2002. Ferreting out Tunneling: An Application to Indian Business Groups. Q. J. Econ. 117, 121-148. https://doi.org/10.1162/003355302753399463

Boubakri, N., Cosset, J.-C., 1998. The Financial and Operating Performance of Newly Privatized Firms: Evidence from Developing Countries. J. Finance 53, 1081-1110. https://doi.org/10.1111/0022-1082.00044

Buchuk, D., Larrain, B., Muñoz, F., Urzúa I., F., 2014. The internal capital markets of business groups: Evidence from intra-group loans. J. financ. econ. 112, 190-212. https://doi.org/10.1016/J.JFINECO.2014.01.003

Chang, S.J., Hong, J., 2000. Economic performance of group-affiliated companies in Korea: intragroup-resource sharing and internal business transactions. Acad. Manag. J. 43, 429448. https://doi.org/10.2307/1556403

Cho, S.-S., El Ghoul, S., Guedhami, O., Suh, J., 2014. Creditor rights and capital structure: Evidence from international data. J. Corp. Financ. 25, 40-60.

Dharmapala, D., Khanna, V., 2013. Corporate Governance, Enforcement, and Firm Value: Evidence from India. J. Law, Econ. Organ. 29, 1056-1084. https://doi.org/10.1093/jleo/ews011

Djankov, S., McLiesh, C., Shleifer, A., 2007. Private credit in 129 countries. J. financ. econ. 84, 299-329. https://doi.org/10.1016/j.jfineco.2006.03.004

Donaldson, G., 1961. Corporate debt capacity. 
Fabozzi, F.J., Markowitz, H.M., 2011. Equity Valuation and Portfolio Management, EBLSchweitzer. Wiley.

Fombrun, C., Shanley, M., 1990. What's in a Name? Reputation Building and Corporate Strategy. Acad. Manag. J. 33, 233-258. https://doi.org/10.2307/256324

Gan, J., 2007. Collateral, debt capacity, and corporate investment: Evidence from a natural $\begin{array}{lllll}\text { experiment. } & \text { J. } & \text { financ. }\end{array}$ https://doi.org/10.1016/J.JFINECO.2006.06.007

Gopalan, R., Nanda, V., Seru, A., 2007. Affiliated firms and financial support: Evidence from Indian business groups. J. financ. econ. 86, 759-795. https://doi.org/10.1016/j.jfineco.2006.09.008

Hart, O., La Porta Drago, R., Lopez-de-Silanes, F., Moore, J., 1997. A new bankruptcy procedure that uses multiple auctions. Eur. Econ. Rev. 41, 461-473. https://doi.org/10.1016/S0014-2921(97)00015-9

Hart, O., Moore, J., 1994. A Theory of Debt Based on the Inalienability of Human Capital. Q. J. Econ. 109, 841-879. https://doi.org/10.2307/2118350

Haselmann, R., Pistor, K., Vig, V., 2010. How Law Affects Lending. Rev. Financ. Stud. 23, 549-580. https://doi.org/10.1093/rfs/hhp073

He, J., Mao, X., Rui, O.M., Zha, X., 2013. Business groups in China. J. Corp. Financ. 22, 166192. https://doi.org/10.1016/j.jcorpfin.2013.05.001

Hoshi, T., Kashyap, A., Scharfstein, D., 1991. Corporate Structure, Liquidity, and Investment: Evidence from Japanese Industrial Groups. Q. J. Econ. 106, 33-60. https://doi.org/10.2307/2937905

Hubbard, R.G., Palia, D., 1999. A Reexamination of the Conglomerate Merger Wave in the 1960s: An Internal Capital Markets View. J. Finance 54, 1131-1152.

Jappelli, T., Pagano, M., 2002. Information sharing, lending and defaults: Cross-country evidence. J. Bank. Financ. 26, 2017-2045. https://doi.org/10.1016/S03784266(01)00185-6

Khanna, T., Palepu, K., 2000. Is Group Affiliation Profitable in Emerging Markets? An Analysis of Diversified Indian Business Groups. J. Finance 55, 867-891. https://doi.org/10.1111/0022-1082.00229

Khanna, T., Yafeh, Y., 2007. Business Groups in Emerging Markets: Paragons or Parasites? J. Econ. Lit. 45, 331-372. https://doi.org/10.1257/jel.45.2.331

King, R.G., Levine, R., 1993. Finance, entrepreneurship and growth. J. Monet. Econ. 32, 513542. https://doi.org/10.1016/0304-3932(93)90028-E 
Koirala, S., Marshall, A., Neupane, S., Thapa, C., 2018. Corporate governance reform and risktaking: Evidence from a quasi-natural experiment in an emerging market. J. Corp. Financ. https://doi.org/10.1016/J.JCORPFIN.2018.08.007

La Porta, R., Lopez-de-Silanes, F., Shleifer, A., Vishny, R., 2002. Investor protection and corporate valuation. J. Finance 57, 1147-1170.

La Porta, R., Lopez-de-Silanes, F., Shleifer, A., Vishny, R.W., 1998. Law and Finance. J. Polit. Econ. 106, 1113-1155. https://doi.org/10.1086/250042

Leary, M.T., Roberts, M.R., 2005. Do Firms Rebalance Their Capital Structures? J. Finance 60, 2575-2619. https://doi.org/10.1111/j.1540-6261.2005.00811.x

Lilienfeld-Toal, U. von, Mookherjee, D., Visaria, S., 2012. The Distributive Impact of Reforms in Credit Enforcement: Evidence From Indian Debt Recovery Tribunals. Econometrica 80, 497-558. https://doi.org/10.3982/ECTA9038

Lin, C., Ma, Y., Malatesta, P., Xuan, Y., 2011. Ownership structure and the cost of corporate borrowing. J. financ. econ. 100, 1-23. https://doi.org/10.1016/j.jfineco.2010.10.012

Myers, S.C., 2003. Financing of Corporations. Handb. Econ. Financ. 1, 215-253. https://doi.org/10.1016/S1574-0102(03)01008-2

Myers, S.C., Majluf, N.S., 1984. Corporate financing and investment decisions when firms have information that investors do not have. J. financ. econ. 13, 187-221. https://doi.org/10.1016/0304-405X(84)90023-0

Pinkowitz, L., Stulz, R., Williamson, R., 2006. Does the contribution of corporate cash holdings and dividends to firm value depend on governance? A cross-country analysis. J. Finance 61, 2725-2751.

Rajan, R.G., Zingales, L., 1995. What Do We Know about Capital Structure? Some Evidence from International Data. J. Finance 50, 1421-1460. https://doi.org/10.1111/j.15406261.1995.tb05184.x

Shane, S., Cable, D., 2002. Network Ties, Reputation, and the Financing of New Ventures. Manage. Sci. 48, 364-381. https://doi.org/10.1287/mnsc.48.3.364.7731

Shin, H.-H., Park, Y.S., 1999. Financing constraints and internal capital markets: Evidence from Korean ‘chaebols'. J. Corp. Financ. 5, 169-191. https://doi.org/10.1016/S09291199(99)00002-4

Taluja, P., Seth, R., Berger, A.N., 2017. Role of Collateral in Mitigating Adverse Selection: Evidence from a Natural Experiment in India, in: EFMA 20th Annual Meeting. Athens.

Townsend, R.M., 1979. Optimal contracts and competitive markets with costly state verification. J. Econ. Theory 21, 265-293. https://doi.org/10.1016/0022-0531(79)90031- 
0

Vig, V., 2013. Access to Collateral and Corporate Debt Structure: Evidence from a Natural Experiment. J. Finance 68, 881-928. https://doi.org/10.1111/jofi.12020

Visaria, S., 2009. Legal Reform and Loan Repayment: The Microeconomic Impact of Debt Recovery Tribunals in India $\dagger$. Am. Econ. J. Appl. Econ. 1, 59-81. https://doi.org/10.1257/app.1.3.59

White, M.J., 1996. The costs of corporate bankruptcy: A US-European comparison, in: Bhandari, J.S., Weiss, L.A. (Eds.), Corporate Bankruptcy: Economic and Legal Perspectives. Cambridge University Press, London : New York, pp. 467-500.

Whited, T.M., Wu, G., 2006. Financial Constraints Risk. Rev. Financ. Stud. 19, 531-559. https://doi.org/10.1093/rfs/hhj012

Williams, R.J., Barrett, J.D., 2000. Corporate Philanthropy, Criminal Activity, and Firm Reputation: Is There a Link? J. Bus. Ethics 26, 341-350. https://doi.org/10.1023/A:1006282312238

Wurgler, J., 2000. Financial markets and the allocation of capital. J. financ. econ. 58, 187-214. https://doi.org/10.1016/S0304-405X(00)00070-2

Zeidan, R., Galil, K., Shapir, O.M., 2018. Do ultimate owners follow the pecking order theory? Q. Rev. Econ. Financ. 67, 45-50. https://doi.org/10.1016/J.QREF.2017.04.008 


\section{Table 1: Descriptive statistics}

Table 1 reports the average of variables (along with the number of observations presented in the second row for each variable) used in the analysis for the segregated two periods, i.e., before the SARFAESI Act (1996-2001) and after the SARFAESI Act (2002-2007). The variables Total Debt, Secured Debt, and Unsecured Debt are scaled by the book value of Total Assets (TA). Size is the natural logarithm of the book value of total assets expressed in millions of Indian currency (INR). Tangibility is net fixed asset as a proportion of book value of Total Assets. Operating profitability is earnings before interest and tax. $M B$ represents the ratio of the market value of shareholders' equity to its book value. *,** and *** denote statistical significance at the $10 \%, 5 \%$ and $1 \%$ levels respectively. The total sample period ranges from the year 1996-2007. Data source: CMIE database.

\begin{tabular}{|c|c|c|c|c|c|}
\hline $\begin{array}{l}\text { Variable } \\
\text { No. of observations }\end{array}$ & Before & After & Diff & t-stat & p-value \\
\hline Total Debt/TA & $\begin{array}{l}0.3811 \\
22,196\end{array}$ & $\begin{array}{l}0.3907 \\
21,681\end{array}$ & $0.0096 * * *$ & 3.0152 & 0.0000 \\
\hline Secured Debt/TA & $\begin{array}{l}0.3280 \\
20,904\end{array}$ & $\begin{array}{l}0.3301 \\
19,633\end{array}$ & $0.0021 * * *$ & 2.9958 & 0.0000 \\
\hline Unsecured Debt/TA & $\begin{array}{l}0.0861 \\
19,012\end{array}$ & $\begin{array}{l}0.1019 \\
17,517\end{array}$ & $0.0158 * * *$ & 6.1463 & 0.0000 \\
\hline Size & $\begin{array}{l}5.7341 \\
22,196\end{array}$ & $\begin{array}{l}5.8306 \\
21,681\end{array}$ & $0.0965 * * *$ & 5.7465 & 0.0000 \\
\hline Tangibility & $\begin{array}{l}0.3788 \\
22,040\end{array}$ & $\begin{array}{l}0.3540 \\
21,276\end{array}$ & $-0.0249 * * *$ & -11.7332 & 0.0000 \\
\hline Operating Profitability & $\begin{array}{l}0.0805 \\
22,196\end{array}$ & $\begin{array}{l}0.1484 \\
21,681\end{array}$ & $0.0679 * * *$ & 7.9553 & 0.0000 \\
\hline MB & $\begin{array}{l}1.17 \\
16,330 \\
\end{array}$ & $\begin{array}{l}2.07 \\
11,902\end{array}$ & $0.9000 * * *$ & 30.75 & 0.0000 \\
\hline
\end{tabular}

Table 2: Descriptive statistics: Firms classified into business groups and unaffiliated stand-alone.

Table 2 reports the average of variables (along with the number of observations presented in the second row for each variable) used in the analysis for unaffiliated standalone (treated) firms and business-group (comparison) firms. The variables are as defined in Table $1 . *$, ** and *** denote statistical significance at 10\%, 5\%, and $1 \%$ levels respectively. The total sample period ranges from the year 1996-2007. Data source: CMIE database.

\begin{tabular}{|c|c|c|c|c|}
\hline $\begin{array}{l}\text { Variable } \\
\text { No. of observations }\end{array}$ & $\begin{array}{l}\text { Unaffiliated } \\
\text { stand-alone } \\
\text { Firms }\end{array}$ & $\begin{array}{l}\text { Business-Group } \\
\text { Firms }\end{array}$ & Diff & t-stat \\
\hline Total Debt/TA & $\begin{array}{l}0.3836 \\
27,956\end{array}$ & $\begin{array}{l}0.3949 \\
15,921\end{array}$ & $0.0113 * * *$ & 8.29 \\
\hline Secured Debt/TA & $\begin{array}{l}0.3188 \\
25404\end{array}$ & $\begin{array}{l}0.3250 \\
15133\end{array}$ & $0.0062 * * *$ & 2.71 \\
\hline Unsecured Debt/TA & $\begin{array}{l}0.0937 \\
22455\end{array}$ & $\begin{array}{l}0.0931 \\
14074\end{array}$ & -0.0006 & -0.63 \\
\hline Size & $\begin{array}{l}5.12 \\
27956\end{array}$ & $\begin{array}{l}7.00 \\
15921\end{array}$ & $1.88 * * *$ & 122.52 \\
\hline Tangibility & $\begin{array}{l}0.3658 \\
27,493\end{array}$ & $\begin{array}{l}0.3673 \\
15823\end{array}$ & 0.0015 & 0.67 \\
\hline Operating Profitability & $\begin{array}{l}0.1187 \\
27,956\end{array}$ & $\begin{array}{l}0.1087 \\
15,921\end{array}$ & 0.0717 & 1.12 \\
\hline MB & $\begin{array}{l}1.3876 \\
16,665\end{array}$ & $\begin{array}{l}1.8166 \\
11,567\end{array}$ & $0.4290 * * *$ & 14.24 \\
\hline
\end{tabular}




\section{Table 3: Univariate difference-in-differences (DiD) in the corporate borrowing.}

Table 3 reports the mean estimates of total debt, secured debt and unsecured debt as a proportion of book value of total as sets for the unaffiliated standalone firms (treated firms) and business group firm (comparison firms) before and after the enactment of the SARFAESI Act in 2002. Before period represents 19962001 and the After period is from 2002-2007. The last column represents the DiD of each of these variables between the treated and comparison groups. *,** and $* * *$ denote statistical significance at $10 \%, 5 \%$ and $1 \%$ levels respectively. The study period is 1996-2007. Data source: CMIE database.

\begin{tabular}{|c|c|c|c|c|c|c|}
\hline $\begin{array}{l}\text { Variable } \\
{[1]}\end{array}$ & $\begin{array}{r}\text { Firnal Capital } \\
\text { Firm-type } \\
{[2]}\end{array}$ & $\begin{array}{r}\text { Before } \\
{[3]} \\
\end{array}$ & $\begin{array}{r}\text { After } \\
{[4]}\end{array}$ & $\begin{array}{c}\text { Diff } \\
{[5]}\end{array}$ & $\begin{array}{r}\text { t-stat } \\
{[6]}\end{array}$ & $\begin{array}{r}\mathrm{DiD} \\
{[7]}\end{array}$ \\
\hline Total Debt/TA & $\begin{array}{r}\text { Treated } \\
\text { Comparison }\end{array}$ & $\begin{array}{l}0.3703 \\
0.3966\end{array}$ & $\begin{array}{l}0.3979 \\
0.3894\end{array}$ & $\begin{array}{r}0.0276 * * * \\
-0.0072 * * *\end{array}$ & $\begin{array}{r}8.8721 \\
-2.5084\end{array}$ & $0.0348 * * *$ \\
\hline Secured Debt/TA & $\begin{array}{r}\text { Treated } \\
\text { Comparison }\end{array}$ & $\begin{array}{l}0.3026 \\
0.3282\end{array}$ & $\begin{array}{l}0.3392 \\
0.3250\end{array}$ & $\begin{array}{l}0.0366 \text { *** } \\
-0.0032\end{array}$ & $\begin{array}{l}10.3761 \\
-1.6620\end{array}$ & $0.0398 * * *$ \\
\hline Unsecured Debt/TA & $\begin{array}{r}\text { Treated } \\
\text { Comparison }\end{array}$ & $\begin{array}{l}0.0844 \\
0.0884\end{array}$ & $\begin{array}{l}0.1198 \\
0.0963\end{array}$ & $\begin{array}{l}0.0354 * * * \\
0.0079 * * *\end{array}$ & $\begin{array}{r}18.0919 \\
5.9098\end{array}$ & $0.0275 * * *$ \\
\hline
\end{tabular}


Table 4: Multivariate analysis.

\section{Access to internal capital and corporate borrowing.}

Table 4. reports the results of DiD regression using the following general specification:

$$
(\text { Total Debt } / T A)_{i t}=\alpha+\beta .\left[\text { CIC }_{i} \times \text { Post }_{t}\right]+\boldsymbol{X}_{i t} \cdot \boldsymbol{\delta}+\left[\boldsymbol{X}_{i t} \times \text { Post }_{t}\right] \cdot \boldsymbol{\vartheta}+\left[\boldsymbol{X}_{i t} \times \text { CIC }_{i}\right] \cdot \boldsymbol{\rho}+\gamma_{i}+\left[\eta_{j} \times \tau_{t}\right]+e_{i t}
$$

where (Total Debt/TA $)_{i t}$ is defined as total debt to book value of total assets in models [1] to [4] and TD-Growth is defined as the growth in total debt in the model [5]. $C I C_{i}$ is an indicator variable that takes the value of one for treated firms (standalone firms) and zero otherwise (business group affiliated firms). Post $t_{t}$ is a categorical variable that takes the value of one for years following and including the year of introduction of the SARFAESI Act, i.e., 2002, and zero otherwise. $\boldsymbol{X}_{i \boldsymbol{t}}$ is a vector of control variables including Size, Tangibility, Operating Profitability, and $M B$, as defined in Table $1 . \gamma_{i}$ controls for the firm fixed effect. The interaction term $\left[\eta_{j} \times \tau_{t}\right]$ controls for time-variant industry-level shocks and $e_{i t}$ is the error term. Standard errors, clustered at the firm level, are reported in parentheses. The entire study period ranges from 1996 to 2007 whereas the shorter study period is from 1998 to 2005. Models [1] [2] [6] and [7] report regression without control variables and all other models report regression with control variables. *, ** and *** denote statistical significance at $10 \%, 5 \%$ and $1 \%$ levels respectively. Source: CMIE database.

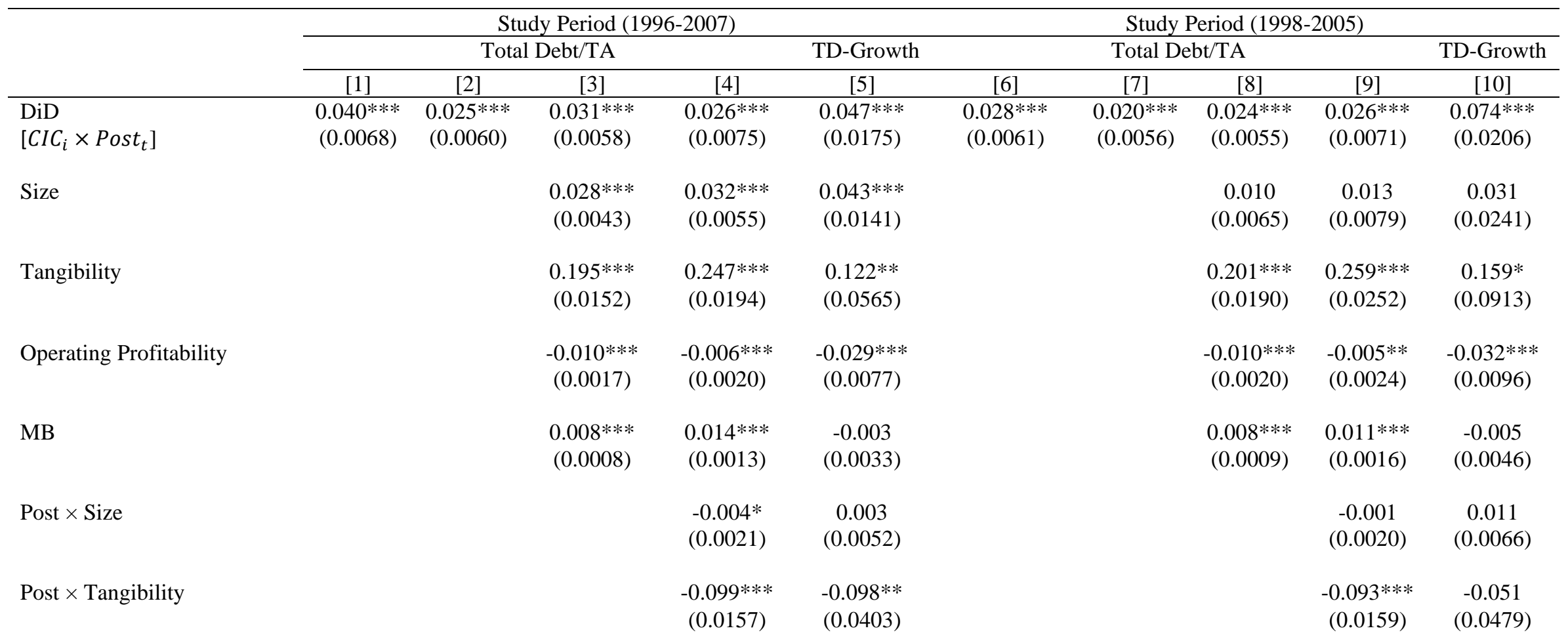




\begin{tabular}{|c|c|c|c|c|c|c|c|c|c|c|}
\hline Post $\times$ Operating Profitability & & & & $\begin{array}{c}-0.006 * * * \\
(0.0013)\end{array}$ & $\begin{array}{c}-0.019 * * * \\
(0.0061)\end{array}$ & & & & $\begin{array}{c}-0.006^{* * *} \\
(0.0014)\end{array}$ & $\begin{array}{c}-0.016 * * \\
(0.0071)\end{array}$ \\
\hline Post $\times$ MB & & & & $\begin{array}{c}-0.006 * * * \\
(0.0013)\end{array}$ & $\begin{array}{c}-0.001 \\
(0.0034)\end{array}$ & & & & $\begin{array}{c}-0.003 * * \\
(0.0014)\end{array}$ & $\begin{array}{c}0.003 \\
(0.0042)\end{array}$ \\
\hline $\mathrm{CIC} \times$ Size & & & & $\begin{array}{c}0.001 \\
(0.0076)\end{array}$ & $\begin{array}{c}0.023 \\
(0.0174)\end{array}$ & & & & $\begin{array}{c}0.001 \\
(0.0121)\end{array}$ & $\begin{array}{c}0.047 \\
(0.0318)\end{array}$ \\
\hline CIC $\times$ Tangibility & & & & $\begin{array}{c}0.036 \\
(0.0300)\end{array}$ & $\begin{array}{c}0.090 \\
(0.0781)\end{array}$ & & & & & $\begin{array}{c}0.136 \\
(0.1292)\end{array}$ \\
\hline $\mathrm{CIC} \times$ Operating Profitability & & & & $\begin{array}{c}0.004 \\
(0.0036)\end{array}$ & $\begin{array}{c}0.001 \\
(0.0147)\end{array}$ & & & & & $\begin{array}{c}0.007 \\
(0.0181)\end{array}$ \\
\hline $\mathrm{CIC} \times \mathrm{MB}$ & & & & $\begin{array}{l}0.003 * * \\
(0.0015)\end{array}$ & $\begin{array}{c}0.001 \\
(0.0038)\end{array}$ & & & & & $\begin{array}{c}0.005 \\
(0.0052)\end{array}$ \\
\hline Firm FE & Yes & Yes & Yes & Yes & Yes & Yes & Yes & Yes & Yes & Yes \\
\hline Industry FE $\times$ Year FE & Yes & Yes & Yes & Yes & Yes & Yes & Yes & Yes & Yes & Yes \\
\hline $\mathrm{R}^{2}$ (Adj.) & 0.73 & 0.70 & 0.72 & 0.72 & 0.19 & 0.81 & 0.78 & 0.79 & 0.80 & 0.21 \\
\hline No. of Firms & 5,049 & 3,764 & 3,764 & 3,747 & 3,714 & 4,535 & 2,896 & 2,896 & 2,896 & 2845 \\
\hline No. of Obs. & 43,877 & 26,638 & 26,638 & 26,638 & 26,302 & 28,533 & 16,411 & 16,411 & 16,411 & 16,127 \\
\hline
\end{tabular}




\section{Table 5: Placebo Test.}

\section{Access to internal capital and corporate borrowing with false shock years.}

Table 5 reports the results of placebo regression results using the following specification:

$$
\begin{gathered}
(\text { Total Debt } / T A)_{i t}=\alpha+\beta_{1} \cdot\left[A F Y_{[-1]} \times C I C_{i}\right]+\beta_{2 \cdot}\left[A F Y_{[-2]} \times C I C_{i}\right]+\beta_{3 \cdot}\left[A F Y_{[-3]} \times\right. \\
\left.C I C_{i}\right]+\boldsymbol{X}_{\boldsymbol{i t}} \cdot \boldsymbol{\delta}+\left[\boldsymbol{X}_{\boldsymbol{i t}} \times C I C_{i}\right] \cdot \boldsymbol{\rho}+\gamma_{i}+\left[\eta_{j} \times \tau_{t}\right]+e_{i t}
\end{gathered}
$$

where $(\text { Total Debt } / T A)_{i t}$ is defined as total debt to book value of total assets. $C I C_{i}$ is an indicator variable that takes the value of one for treated firms and zero otherwise. $A F Y_{[-1]}, A F Y_{[-2]}$, and $A F Y_{[-3]}$ are categorical variables that take the value of one for one, two and three years respectively following and including the false shock year $\left(F S Y_{[-t]}\right)$, and zero otherwise. Our Placebo experiment uses three different FSYs, i.e., one year $\left[F S Y_{[-1]}\right]$, two year $\left[F S Y_{[-2]}\right]$, and three year $\left[F S Y_{[-3]}\right]$ before the true creditor protection reform Act in 2002. $\boldsymbol{X}_{\boldsymbol{i t}}$ is a vector of control variables including Size, Tangibility, Operating Profitability and $M B$, all defined in Table 1. $\gamma_{i}$ controls for the firm fixed effect. The interaction term $\left[\eta_{j} \times \tau_{t}\right]$ controls for time-variant industry-level shocks and $e_{i t}$ is the error term. Standard errors, clustered at the firm level, are reported in parentheses. $*, * *$ and $* * *$ denote statistical significance at $10 \%, 5 \%$ and $1 \%$ levels respectively.

\begin{tabular}{|c|c|c|c|c|}
\hline & [1] & [2] & [3] & [4] \\
\hline$A F Y_{[-1]}$ & $\begin{array}{c}0.002 \\
(0.0065)\end{array}$ & & & $\begin{array}{c}0.002 \\
(0.0052)\end{array}$ \\
\hline$A F Y_{[-2]}$ & & $\begin{array}{c}0.001 \\
(0.0061)\end{array}$ & & $\begin{array}{c}-0.005 \\
(0.0047)\end{array}$ \\
\hline$A F Y_{[-3]}$ & & & $\begin{array}{c}0.005 \\
(0.0060)\end{array}$ & $\begin{array}{c}0.007 \\
(0.0054)\end{array}$ \\
\hline Size & $\begin{array}{c}-0.009 \\
(0.0095)\end{array}$ & $\begin{array}{c}-0.009 \\
(0.0096)\end{array}$ & $\begin{array}{c}-0.010 \\
(0.0096)\end{array}$ & $\begin{array}{c}-0.010 \\
(0.0097)\end{array}$ \\
\hline Tangibility & $\begin{array}{c}0.194 * * * \\
(0.0225)\end{array}$ & $\begin{array}{c}0.194 * * * \\
(0.0224)\end{array}$ & $\begin{array}{c}0.194 * * * \\
(0.0224)\end{array}$ & $\begin{array}{c}0.193 * * * \\
(0.0224)\end{array}$ \\
\hline Operating Profitability & $\begin{array}{c}-0.014 * * * \\
(0.0028)\end{array}$ & $\begin{array}{c}-0.014 * * * \\
(0.0028)\end{array}$ & $\begin{array}{c}-0.014 * * * \\
(0.0028)\end{array}$ & $\begin{array}{c}-0.014 * * * \\
(0.0028)\end{array}$ \\
\hline MB & $\begin{array}{c}0.011^{* * *} * \\
(0.0018)\end{array}$ & $\begin{array}{c}0.011^{* * *} * \\
(0.0018)\end{array}$ & $\begin{array}{c}0.011 * * * \\
(0.0018)\end{array}$ & $\begin{array}{c}0.011^{* * *} * \\
(0.0018)\end{array}$ \\
\hline $\mathrm{CIC} \times$ Size & $\begin{array}{c}0.002 \\
(0.0137)\end{array}$ & $\begin{array}{c}0.003 \\
(0.0143)\end{array}$ & $\begin{array}{c}-0.000 \\
(0.0146)\end{array}$ & $\begin{array}{c}0.000 \\
(0.0149)\end{array}$ \\
\hline CIC $\times$ Tangibility & $\begin{array}{c}0.014 \\
(0.0352)\end{array}$ & $\begin{array}{c}0.014 \\
(0.0351)\end{array}$ & $\begin{array}{c}0.011 \\
(0.0352)\end{array}$ & $\begin{array}{c}0.011 \\
(0.0353)\end{array}$ \\
\hline $\mathrm{CIC} \times$ Operating Profitability & $\begin{array}{c}0.006 \\
(0.0061)\end{array}$ & $\begin{array}{c}0.006 \\
(0.0061)\end{array}$ & $\begin{array}{c}0.006 \\
(0.0062)\end{array}$ & $\begin{array}{c}0.006 \\
(0.0062)\end{array}$ \\
\hline $\mathrm{CIC} \times \mathrm{MB}$ & $\begin{array}{l}0.005 * * \\
(0.0021)\end{array}$ & $\begin{array}{l}0.005^{* *} \\
(0.0021)\end{array}$ & $\begin{array}{l}0.005^{* *} \\
(0.0021)\end{array}$ & $\begin{array}{l}0.004 * * \\
(0.0021)\end{array}$ \\
\hline $\begin{array}{l}\text { Firm FE } \\
\text { Industry FE } \times \text { Year FE }\end{array}$ & $\begin{array}{l}\text { Yes } \\
\text { Yes }\end{array}$ & $\begin{array}{l}\text { Yes } \\
\text { Yes }\end{array}$ & $\begin{array}{l}\text { Yes } \\
\text { Yes }\end{array}$ & $\begin{array}{l}\text { Yes } \\
\text { Yes }\end{array}$ \\
\hline $\begin{array}{l}\mathrm{R}^{2}(\mathrm{Adj} .) \\
\text { No. of Firms } \\
\text { No. of Obs. }\end{array}$ & $\begin{array}{c}0.79 \\
3795 \\
15,438\end{array}$ & $\begin{array}{c}0.79 \\
3795 \\
15,438\end{array}$ & $\begin{array}{c}0.79 \\
3795 \\
15,438\end{array}$ & $\begin{array}{c}0.79 \\
3795 \\
15.438\end{array}$ \\
\hline
\end{tabular}
The study period ranged from 1996-2001. Data source: CMIE database. 
Table 6: Robustness Test.

Access to internal capital and corporate borrowing with secured and unsecured borrowing as dependent variables.

Table 6 reports the results of DiD regression results using the following general equation:

$$
\left(D_{e b t} / T A\right)_{i t}=\alpha+\beta .\left[\text { CIC }_{i} \times \text { Post }_{t}\right]+\boldsymbol{X}_{i t} . \boldsymbol{\delta}+\left[\boldsymbol{X}_{i t} \times \text { Post }_{t}\right] \cdot \boldsymbol{\vartheta}+\left[\boldsymbol{X}_{i t} \times \text { CIC }_{i}\right] . \boldsymbol{\rho}+\gamma_{i}+\left[\eta_{j} \times \tau_{t}\right]+e_{i t}
$$

where $(D e b t / T A)_{i t}$ is secured debt to total assets (results reported in models 1 to 6 ) and unsecured debt to total assets (results reported in models 7 to 12 ). CIC $_{i}$ is an indicator variable that takes the value of one for treated firms and zero otherwise. Post $t_{t}$ is a categorical variable that takes the value of one for years following and including the year of introduction of the SARFAESI Act, i.e., 2002, and zero otherwise. $\boldsymbol{X}_{\boldsymbol{i t}}$ is a vector of control variables including Size, Tangibility, Operating Profitability, and MB, as defined in Table 1. $\gamma_{i}$ controls for the firm fixed effect. The interaction term $\left[\eta_{j} \times \tau_{t}\right]$ controls for time-variant industry-level shocks and $e_{i t}$ is the error term. Standard errors, clustered at the firm level, are reported in parentheses. Models [2], [5], [8] and [11] are for the subsample of firms with non-missing control variables. Models 1-3 and 7-8 report the results for the entire study period of 1996-2007, whereas models 4-6 and 10-12 present the results for a shorter study period of 1998-2005. *,** and *** denote statistical significance at 10\%, $5 \%$ and $1 \%$ levels respectively. Source: CMIE database.

\begin{tabular}{|c|c|c|c|c|c|c|c|c|c|c|c|c|}
\hline & \multirow{2}{*}{\multicolumn{6}{|c|}{$\frac{\text { Secured Debt }}{T A}$}} & \multirow{2}{*}{\multicolumn{6}{|c|}{$\frac{\text { Unsecured Debt }}{T A}$}} \\
\hline & & & & & & & & & & & & \\
\hline & \multicolumn{3}{|c|}{ Study Period (1996-2007) } & \multicolumn{3}{|c|}{ Study Period (1998-2005) } & \multicolumn{3}{|c|}{ Study Period (1996-2007) } & \multicolumn{3}{|c|}{ Study Period (1998-2005) } \\
\hline & [1] & {$[2]$} & [3] & {$[4]$} & [5] & {$[6]$} & {$[7]$} & {$[8]$} & [9] & {$[10]$} & {$[11]$} & [12] \\
\hline DiD & $0.035^{* * *}$ & $0.018^{* * *}$ & $0.020 * * *$ & $0.025 * * *$ & $0.023 * * *$ & $0.023 * * *$ & $0.024 * * *$ & $0.012 * * *$ & $0.013^{* *}$ & $0.019 * * *$ & $0.014 * * *$ & $0.010^{* *}$ \\
\hline$\left[\right.$ CIC $_{i} \times$ Post $\left._{t}\right]$ & $(0.0070)$ & $(0.0056)$ & $(0.0073)$ & $(0.0062)$ & $(0.0053)$ & $(0.0067)$ & $(0.0056)$ & $(0.0039)$ & $(0.0052)$ & $(0.0050)$ & $(0.0037)$ & $(0.0049)$ \\
\hline Size & & & $\begin{array}{c}0.031 * * * \\
(0.0052)\end{array}$ & & & $\begin{array}{l}0.017 * * \\
(0.0083)\end{array}$ & & & $\begin{array}{l}-0.008 * * \\
(0.0040)\end{array}$ & & & $\begin{array}{c}-0.015 * * * \\
(0.0058)\end{array}$ \\
\hline Tangibility & & & $\begin{array}{c}0.235 * * * \\
(0.0196)\end{array}$ & & & $\begin{array}{c}0.256 * * * \\
(0.0277)\end{array}$ & & & $\begin{array}{c}0.022 \\
(0.0134)\end{array}$ & & & $\begin{array}{c}0.023 \\
(0.0191)\end{array}$ \\
\hline Operating Profitability & & & $\begin{array}{c}-0.007 * * * \\
(0.0024)\end{array}$ & & & $\begin{array}{l}-0.006^{*} \\
(0.0031)\end{array}$ & & & $\begin{array}{c}-0.001 \\
(0.0016)\end{array}$ & & & $\begin{array}{c}-0.003 \\
(0.0022)\end{array}$ \\
\hline MB & & & $\begin{array}{c}0.010 * * * \\
(0.0014)\end{array}$ & & & $\begin{array}{l}0.009 * * * \\
(0.0017)\end{array}$ & & & $\begin{array}{l}0.005 * * * \\
(0.0011)\end{array}$ & & & $\begin{array}{c}0.004 * * * \\
(0.0014)\end{array}$ \\
\hline Post $\times$ Size & & & $\begin{array}{l}-0.004 * * \\
(0.0021)\end{array}$ & & & $\begin{array}{c}-0.001 \\
(0.0019)\end{array}$ & & & $\begin{array}{c}-0.001 \\
(0.0015)\end{array}$ & & & $\begin{array}{c}-0.002 \\
(0.0014)\end{array}$ \\
\hline Post $\times$ Tangibility & & & $\begin{array}{c}-0.070 * * * \\
(0.0156)\end{array}$ & & & $\begin{array}{c}-0.075 * * * \\
(0.0156)\end{array}$ & & & $\begin{array}{l}-0.024 * * \\
(0.0115)\end{array}$ & & & $\begin{array}{l}-0.019 * \\
(0.0113)\end{array}$ \\
\hline
\end{tabular}




\begin{tabular}{|c|c|c|c|c|c|c|c|c|c|c|c|c|}
\hline Post $\times$ Operating Profitability & & & $\begin{array}{c}-0.007 * * * \\
(0.0016)\end{array}$ & & & $\begin{array}{c}-0.008 * * * \\
(0.0015)\end{array}$ & & & $\begin{array}{l}-0.002 * \\
(0.0011)\end{array}$ & & & $\begin{array}{c}-0.000 \\
(0.0009)\end{array}$ \\
\hline Post $\times$ MB & & & $\begin{array}{c}-0.006 * * * \\
(0.0013)\end{array}$ & & & $\begin{array}{c}-0.003 * \\
(0.0015)\end{array}$ & & & $\begin{array}{c}0.001 \\
(0.0010)\end{array}$ & & & $\begin{array}{c}0.001 \\
(0.0011)\end{array}$ \\
\hline $\mathrm{CIC} \times$ Size & & & $\begin{array}{c}0.011^{*} \\
(0.0067)\end{array}$ & & & $\begin{array}{c}0.009 \\
(0.0110)\end{array}$ & & & $\begin{array}{c}-0.009 \\
(0.0064)\end{array}$ & & & $\begin{array}{c}-0.008 \\
(0.0099)\end{array}$ \\
\hline CIC $\times$ Tangibility & & & $\begin{array}{c}0.018 \\
(0.0293)\end{array}$ & & & $\begin{array}{c}0.037 \\
(0.0382)\end{array}$ & & & $\begin{array}{l}0.042 * * \\
(0.0195)\end{array}$ & & & $\begin{array}{c}0.041 \\
(0.0268)\end{array}$ \\
\hline $\mathrm{CIC} \times$ Operating Profitability & & & $\begin{array}{c}0.000 \\
(0.0047)\end{array}$ & & & $\begin{array}{c}-0.002 \\
(0.0051)\end{array}$ & & & $\begin{array}{c}0.003 \\
(0.0042)\end{array}$ & & & $\begin{array}{c}0.005 \\
(0.0048)\end{array}$ \\
\hline $\mathrm{CIC} \times \mathrm{MB}$ & & & $\begin{array}{c}0.002 \\
(0.0015)\end{array}$ & & & $\begin{array}{c}0.001 \\
(0.0019)\end{array}$ & & & $\begin{array}{c}0.002 \\
(0.0012)\end{array}$ & & & $\begin{array}{c}0.002 \\
(0.0016)\end{array}$ \\
\hline Firm FE & Yes & Yes & Yes & Yes & Yes & Yes & Yes & Yes & Yes & Yes & Yes & Yes \\
\hline Industry FE $\times$ Year FE & Yes & Yes & Yes & Yes & Yes & Yes & Yes & Yes & Yes & Yes & Yes & Yes \\
\hline $\mathrm{R}^{2}$ (Adj.) & 0.70 & 0.68 & 0.70 & 0.79 & 0.76 & 0.77 & 0.59 & 0.50 & 0.51 & 0.68 & 0.58 & 0.59 \\
\hline No. of Firms & 4,764 & 3,639 & 3,625 & 4,249 & 2,789 & 2,787 & 4,681 & 3,393 & 3,380 & 4,100 & 2,584 & 2,580 \\
\hline No. of Obs. & 40,537 & 25,393 & 25,393 & 26,360 & 15,587 & 15,587 & 36,146 & 21,946 & 21,946 & 23,622 & 13,512 & 13,512 \\
\hline
\end{tabular}


Table 7: Robustness Test of Access to Internal Capital and Corporate Borrowing. DiD Regression with treated and comparison firms based on internal capital generation rate (ICGR).

Table 7 reports the results of DiD regression using the regression equation:

$$
\left(D_{e b t} / T A\right)_{i t}=\alpha+\beta .\left[\text { LowI }_{i} \times \text { Post }_{t}\right]+\boldsymbol{X}_{i t} \cdot \boldsymbol{\delta}+\left[\boldsymbol{X}_{i t} \times \text { Post }_{t}\right] . \boldsymbol{\vartheta}+\left[\boldsymbol{X}_{i t} \times \text { LowIC }_{i}\right] . \boldsymbol{\rho}+\gamma_{i}+\left[\eta_{j} \times \tau_{t}\right]+e_{i t}
$$

where $(\text { Debt/TA })_{i t}$ is the dependent variable measuring different forms of corporate borrowing (total, secured and unsecured) scaled by total assets $(T A)$. ${ }_{\text {LowIC }}$ is a categorical variable that takes the value of one for the firms falling in the lower tercile based on firms' three-year average of ICGR before the SARFAESI Act, i.e., from 1999 to 2001, and zero for the firms falling in the upper tercile. We compute ICGR as ICGR $=$ ROE $\times(1-$ dividend payout ratio). Post $t_{t}$ is a categorical variable that takes the value of one for years following and including the year of introduction of the SARFAESI Act, i.e., 2002, and zero otherwise. $\boldsymbol{X}_{i t}$ is a vector of control variables including Size, Tangibility, Operating Profitability and MB as defined in Table 1. $\gamma_{i}$ controls for the firm fixed effect. The interaction term $\left[\eta_{j} \times \tau_{t}\right]$ controls for time-variant industry-level shocks and $e_{i t}$ is the error term. Standard errors, clustered at the firm level, are reported in parentheses. For each dependent variable, i.e., $\frac{\text { Total Debt }}{T A}, \frac{\text { Secured Debt }}{T A}$, and $\frac{\text { Unsecured Debt }}{T A}$, models [1], [3] and [5] report the DiD coefficient without control variables and Models [2], [4], and [6] includes additional firm controls. *, ** and *** denote statistical significance at 10\%, 5\% and 1\% levels respectively. The sample period ranges from 1996 to 2007. Data source: CMIE database.

\begin{tabular}{|c|c|c|c|c|c|c|}
\hline & \multicolumn{2}{|c|}{$\frac{\text { Total Debt }}{T A}$} & \multicolumn{2}{|c|}{$\frac{\text { Secured Debt }}{T A}$} & \multicolumn{2}{|c|}{$\frac{\text { Unsecured Debt }}{T A}$} \\
\hline & [1] & [2] & [3] & [4] & [5] & [6] \\
\hline $\begin{array}{l}\mathrm{DiD} \\
{\left[\text { LowIC }_{i} \times \text { Post }_{t}\right]}\end{array}$ & $\begin{array}{l}0.096 * * * \\
(0.0081)\end{array}$ & $\begin{array}{c}0.077 * * * \\
(0.0100)\end{array}$ & $\begin{array}{l}0.081 * * * \\
(0.0074)\end{array}$ & $\begin{array}{l}0.072 * * * \\
(0.0089)\end{array}$ & $\begin{array}{l}0.014 * * \\
(0.0055)\end{array}$ & $\begin{array}{c}0.004 \\
(0.0066)\end{array}$ \\
\hline Tangibility & & $\begin{array}{c}0.276 * * * \\
(0.0292)\end{array}$ & & $\begin{array}{c}0.262 * * * \\
(0.0302)\end{array}$ & & $\begin{array}{c}0.014 \\
(0.0203)\end{array}$ \\
\hline Size & & $\begin{array}{c}0.040 * * * \\
(0.0085)\end{array}$ & & $\begin{array}{c}0.047 * * * \\
(0.0082)\end{array}$ & & $\begin{array}{c}-0.015 * * * \\
(0.0057)\end{array}$ \\
\hline MB & & $\begin{array}{c}0.012 * * * \\
(0.0017)\end{array}$ & & $\begin{array}{c}0.009 * * * \\
(0.0019)\end{array}$ & & $\begin{array}{l}0.003 * * \\
(0.0014)\end{array}$ \\
\hline Profitability & & $\begin{array}{l}-0.005 \\
(0.0033)\end{array}$ & & $\begin{array}{c}0.001 \\
(0.0042)\end{array}$ & & $\begin{array}{c}-0.005 \\
(0.0033)\end{array}$ \\
\hline Post $\times$ Size & & $-0.005 * *$ & & -0.003 & & $-0.004 * *$ \\
\hline
\end{tabular}


(0.0025)

(0.0023)

(0.0017)

Post $\times$ Tangibility

$-0.031$

(0.0217)

$-0.016$

$-0.008$

$-0.006 * * *$

(0.0205)

(0.0162)

Post $\times$ Profitability

(0.0014)

$-0.008 * * *$

$-0.001$

$-0.004 * *$

(0.0016)

(0.0009)

Post $\times$ MB

(0.0015)

$-0.004 * *$

0.001

$-0.003$

(0.0016)

(0.0014)

Low IC $\times$ Size

(0.0094)

$-0.021 * *$

$0.022 * * *$

(0.0076)

Low IC $\times$ Tangibility

$-0.166 * * *$

(0.0087)

$-0.031$

(0.0372)

$-0.128 * * *$

(0.0263)

Low IC $\times$ Profitability

0.006*

(0.0036)

(0.0354)

$0.008^{*}$

$-0.004$

(0.0044)

\begin{tabular}{|c|c|c|c|c|c|c|}
\hline Low IC $\times \mathrm{MB}$ & & $\begin{array}{c}-0.001 \\
(0.0019)\end{array}$ & & $\begin{array}{c}-0.004 * * \\
(0.0016)\end{array}$ & & $\begin{array}{c}0.003 \\
(0.0017) \\
\end{array}$ \\
\hline Firm FE & Yes & Yes & Yes & Yes & Yes & Yes \\
\hline Industry $\mathrm{FE} \times$ Year FE & Yes & Yes & Yes & Yes & Yes & Yes \\
\hline $\mathrm{R}^{2}$ (Adj.) & 0.73 & 0.75 & 0.71 & 0.73 & 0.49 & 0.51 \\
\hline No. of Firms & 1,978 & 1,978 & 1,897 & 1,897 & 1,772 & 1,772 \\
\hline No. of Obs. & 15,128 & 15,128 & 14,366 & 14,366 & 12,235 & 12,235 \\
\hline
\end{tabular}


Table 8. Robustness Test of Access to Internal Capital and Corporate Borrowing. DiDiD Regression with treated and comparison firms based on Internal Capital Generation Rate (ICGR).

Table 8 reports the results of DiDiD regression using the regression equation:

$$
\begin{aligned}
\left(\text { Debt }_{T} \mathrm{TA}\right)_{i t}=\alpha & +\omega \cdot\left[\text { CIC }_{i} \times \text { Post }_{t} \times \text { Low IC }_{i}\right]+\beta \cdot\left[\text { CIC }_{i} \times \text { Post }_{t}\right]+\lambda .\left[\text { Low IC }_{i} \times \text { Post }_{t}\right] \\
& +\boldsymbol{X}_{\boldsymbol{i t}} \cdot \boldsymbol{\delta}+\left[\boldsymbol{X}_{\boldsymbol{i t}} \times \text { Post }_{t}\right] \boldsymbol{\vartheta}+\left[\boldsymbol{X}_{\boldsymbol{i t}} \times \text { Low IC } C_{i}\right] \cdot \boldsymbol{\rho}+\gamma_{i}+\left[\eta_{j} \times \tau_{t}\right]+e_{i t}
\end{aligned}
$$

where $(D e b t / T A)_{i t}$ is the dependent variable measuring different forms of corporate borrowing (total, secured and unsecured) scaled by total assets (TA). $C I C_{i}$ is an indicator variable that takes the value of one for treated firms and zero otherwise. Post $t$ is a categorical variable that takes the value of one for years following and including the year of introduction of the SARFAESI Act, i.e., 2002, and zero otherwise. Low $I C_{i}$ is a categorical variable that takes a value of one for the firms falling in the lower tercile based on a three year average of ICGR before the SARFAESI Act, i.e., from 1999 to 2001 and zero for the firms falling in the upper tercile. We compute ICGR as ICGR $=R O E \times(1-$ dividend payout ratio $)$. $\boldsymbol{X}_{i t}$ is a vector of control variables including Size, Tangibility, Operating Profitability, and $M B$ as defined in Table $1 . \gamma_{i}$ controls for the firm fixed effect. The interaction term $\left[\eta_{j} \times \tau_{t}\right]$ controls for time-variant industry-level shocks and $e_{i t}$ is the error term. Standard errors, clustered at the firm level, are reported in parentheses. For each dependent variable, i.e., $\frac{\text { Total Debt }}{T A}, \frac{\text { Secured Debt }}{T A}$, and $\frac{\text { Unsecured Debt }}{T A}$, models [1], [3] and [5] reports the DiDiD and DiD coefficients without control variables. Model [2], [4], and [6] includes additional firm controls. *** and *** denote statistical significance at $10 \%, 5 \%$ and $1 \%$ levels respectively. The sample period

\begin{tabular}{|c|c|c|c|c|c|c|}
\hline & \multirow{2}{*}{\multicolumn{2}{|c|}{$\frac{\text { Total Debt }}{\text { TA }}$}} & \multirow{2}{*}{\multicolumn{2}{|c|}{$\frac{\text { Secured Debt }}{T A}$}} & \multirow{2}{*}{\multicolumn{2}{|c|}{$\frac{\text { Unsecured Debt }}{T A}$}} \\
\hline & & & & & & \\
\hline & {$[1]$} & [2] & {$[3]$} & [4] & {$[5]$} & {$[6]$} \\
\hline DiDiD & $0.026 * * *$ & $0.027 * *$ & $0.037 * * *$ & $0.033 * * *$ & -0.001 & 0.000 \\
\hline$\left[\right.$ CIC $_{i} \times$ Post $_{t} \times$ Low IC $\left.C_{i}\right]$ & $(0.010)$ & $(0.0120)$ & $(0.0093)$ & $(0.0104)$ & $(0.0081)$ & $(0.0085)$ \\
\hline $\begin{array}{l}\text { DiD-CIC } \\
{\left[\text { CIC }_{i} \times \text { Post }_{t}\right]}\end{array}$ & $\begin{array}{c}0.079 * * * \\
(0.0106)\end{array}$ & $\begin{array}{c}0.060 * * * \\
(0.0124)\end{array}$ & $\begin{array}{c}0.056^{* * * *} \\
(0.0092)\end{array}$ & $\begin{array}{c}0.052 * * * \\
(0.0106)\end{array}$ & $\begin{array}{c}0.014 * \\
(0.0076)\end{array}$ & $\begin{array}{c}0.004 \\
(0.0085)\end{array}$ \\
\hline $\begin{array}{l}\text { DiD-Low IC } \\
{\left[\text { Low IC }_{i} \times \text { Post }_{t}\right]}\end{array}$ & $\begin{array}{c}-0.017 \\
(0.0154)\end{array}$ & $\begin{array}{c}-0.016 \\
(0.0173)\end{array}$ & $\begin{array}{c}-0.007 \\
(0.0061)\end{array}$ & $\begin{array}{c}-0.008 \\
(0.0084)\end{array}$ & $\begin{array}{c}-0.003 \\
(0.0029)\end{array}$ & $\begin{array}{c}-0.004 \\
(0.0035)\end{array}$ \\
\hline Tangibility & & $\begin{array}{c}0.226 * * * \\
(0.0263)\end{array}$ & & $\begin{array}{c}0.212 * * * \\
(0.0269)\end{array}$ & & $\begin{array}{c}-0.001 \\
(0.0178)\end{array}$ \\
\hline Size & & $\begin{array}{c}0.060 * * * \\
(0.0077)\end{array}$ & & $\begin{array}{c}0.060 * * * \\
(0.0080)\end{array}$ & & $\begin{array}{c}-0.006 \\
(0.0060)\end{array}$ \\
\hline MB & & $0.009 * * *$ & & $0.008 * * *$ & & $0.003 * *$ \\
\hline
\end{tabular}
ranges from 1996 to 2007. Data source: CMIE database. 
Profitability

Post $\times$ Size

Post $\times$ Profitability

Post $\times$ MB

Low IC $\times$ Size

Low IC $\times$ Tangibility

Low IC $\times$ Profitability

Low IC $\times$ MB

Firm FE

Industry FE $\times$ Year FE

$\mathrm{R}^{2}$ (Adj.)

No. of Firms

No. of Obs.
(0.0015)

$-0.005$

(0.0033)

$-0.003$

(0.0026)

$-0.032$

(0.0218)

$-0.006 * * *$

(0.0013)

$-0.004 * *$

(0.0015)

$-0.003$

(0.0095)

$-0.162 * * *$

(0.0374)

$0.006 *$

(0.0036)

(0.0016)

0.001

(0.0042)

$-0.001$

(0.0025)

$-0.019$

(0.0206)

$-0.008 * * *$

(0.0016)

$-0.004 * *$

(0.0015)

$-0.020 * *$

(0.0087)

$-0.123 * * *$

(0.0356)

$-0.004$

(0.0045)

$-0.003 * *$

(0.0016)

(0.0019)

Yes

Yes

0.75

1,978

15,128
Yes

Yes $\quad$ Yes

$0.73 \quad 0.49$

$\begin{array}{ll}0.73 & \\ 1,897 & 1,772\end{array}$

$14,366 \quad 12,235$
(0.0012)

$-0.005$

(0.0033)

$-0.004 *$

(0.0018)

$-0.008$

(0.0162)

$-0.001$

(0.0009)

0.001

(0.0014)

$0.022 * * *$

(0.0076)

$-0.031$

(0.0263)

$0.008^{*}$

(0.0044)

0.003

(0.0017)

Yes

0.51

1,772

12,235 


\section{Table 9: PSM-DiD Regression.}

Table 9 reports the propensity-matched DiD regression results.

Panel A reports the probit model represented by the following equation:

$$
C I C_{i}=\alpha+\boldsymbol{X}_{i t} \cdot \boldsymbol{\beta}+\eta_{j}+e_{i t},
$$

where $C I C_{i}$ is an indicator variable that takes the value of one for firms with constrained access to internal capital (treated firms) and zero otherwise (comparison firms). $\boldsymbol{X}_{\boldsymbol{i t}}$ is a vector of control variables including Size, Tangibility, Operating Profitability and $M B$, all defined in Table 1. $\eta_{j}$ is the industry fixed effect. The sample period for the probit model is from 1998 to 2001. Column 1 of Panel A presents the pre-SARFAESI Act probit model predicting the likelihood of having constrained access to internal capital (i.e., likelihood to be treated firms) from the entire sample of firms with no missing control variables from 1998 to 2005. Column 2 presents the probit likelihood model for matched treated and comparison firms using PSM without replacement.

Panel A: Pre-SARFAESI Act Propensity-Score Matching: Probit Model

\begin{tabular}{lcc}
\hline & Total Sample[1] & Post-matched Diagnostic [2] \\
\hline Size & $-0.533^{* * *}$ & 0.022 \\
Tangibility & $(0.0183)$ & $(0.0244)$ \\
& $0.340 * * *$ & -0.088 \\
Operating Profitability & $(0.0741)$ & $(0.0950)$ \\
& -0.010 & 0.028 \\
MB & $(0.0225)$ & $(0.0280)$ \\
& -0.005 & 0.005 \\
Industry FE & $(0.0059)$ & $(0.0070)$ \\
\hline Pseudo-R & Yes & Yes \\
Prob $>\chi^{2}$ & 0.2390 & 0.0010 \\
No. of Obs. & 0.00 & 0.29 \\
\hline
\end{tabular}

Panel B reports the mean of the matched pairs treated and comparison firms along with the difference and tstatistics for the pre-SARFAESI Act period (1998-2001).

Panel B: Pre-SARFAESI Act Comparison between Matched Treated and Comparison Firms

\begin{tabular}{llllc}
\hline Variables & $\begin{array}{l}\text { Mean Treated } \\
\text { (a) }\end{array}$ & $\begin{array}{l}\text { Mean Comparison } \\
\text { (b) }\end{array}$ & $\begin{array}{l}\text { Difference } \\
\text { (a-b) }\end{array}$ & t-stat \\
\hline Size & 6.30 & 6.31 & -0.01 & -0.43 \\
Tangibility & 0.3783 & 0.3692 & 0.0091 & 1.46 \\
Operating Profitability & 0.1008 & 0.1093 & -0.0085 & -0.39 \\
MB & 1.41 & 1.43 & -0.02 & -0.24 \\
\hline
\end{tabular}

Panel C reports the DiD regressions of propensity-matched pairs of firms from Panel A as represented by the following equation:

$$
(D e b t / T A)_{i t}=\alpha+\beta \cdot\left[C I C_{i} \times \text { Post }_{t}\right]+\boldsymbol{X}_{i t} \cdot \boldsymbol{\delta}+\gamma_{i}+\left[\eta_{j} \times \tau_{t}\right]+e_{i t},
$$

where $(D e b t / T A)_{i t}$ is debt to total assets. $C I C_{i}$ is an indicator variable that takes the value of one for treated firms and zero otherwise. Post $t_{t}$ is a categorical variable that takes the value of one for four years following and including the year of introduction of the SARFAESI Act, i.e., 2002, and zero for four years before 2002. $\boldsymbol{X}_{i t}$ is a vector of control variables as defined in Table 1. $\gamma_{i}$ controls for the firm fixed effect. The interaction term $\left[\eta_{j} \times \tau_{t}\right]$ controls for time-variant industry-level shocks and $e_{i t}$ is the error term. While models [1] and [2] show DiD regression results for total debt to total assets, models [3] and [4] are the results for secured debt to total assets.

\begin{tabular}{|c|c|c|c|c|}
\hline & [1] & [2] & [3] & [4] \\
\hline $\begin{array}{l}\mathrm{DiD} \\
{\left[C I C_{i} \times \text { Post }_{t}\right]}\end{array}$ & $\begin{array}{l}0.028 * * * \\
(0.0093)\end{array}$ & $\begin{array}{c}0.029 * * * \\
(0.0084)\end{array}$ & $\begin{array}{l}0.026 * * \\
(0.0094)\end{array}$ & $\begin{array}{l}0.024 * * \\
(0.0085)\end{array}$ \\
\hline Size & & $\begin{array}{c}0.008 \\
(0.0130)\end{array}$ & & $\begin{array}{c}0.009 \\
(0.0113)\end{array}$ \\
\hline Tangibility & & $\begin{array}{c}0.035 \\
(0.0390)\end{array}$ & & $\begin{array}{c}0.0304 \\
(0.0384)\end{array}$ \\
\hline
\end{tabular}

Panel C: PSM-DiD Regression 
Firm FE

Industry FE* Year FE

Yes Adj. $\mathrm{R}^{2}$

No. of Firms

Yes

Yes

Yes

Yes

No. of Obs.

Panel D reports the univariate DiD of corporate borrowing (total and secured) along with the before and after mean difference of the matched treated and comparison groups. $*, * *$ and $* * *$ denote statistical significance at $10 \%, 5 \%$ and $1 \%$ significance levels respectively. The sample period ranges from 1998 to 2005. Source: CMIE database.

Panel D. Univariate DiD of Corporate Borrowing of Matched Treated and Comparison Groups

\begin{tabular}{|c|c|c|c|c|c|}
\hline Group & & (After) & (Before) & $\begin{array}{l}\text { Difference } \\
(a-b)\end{array}$ & t-stat \\
\hline \multirow[t]{2}{*}{ Treated } & $(\text { Total Debt/TA })_{i t}$ & 0.3971 & 0.3719 & $0.0252 * * *$ & 3.84 \\
\hline & $(\text { Secured Debt/TA })_{i t}$ & 0.3016 & 0.2735 & $0.0281 * * *$ & 3.76 \\
\hline \multirow[t]{3}{*}{ Comparison } & $(\text { Total Debt } / T A)_{i t}$ & 0.3765 & 0.3772 & -0.0007 & -0.11 \\
\hline & $(\text { Secured Debt/TA })_{i t}$ & 0.3016 & 0.3018 & -0.0002 & -0.34 \\
\hline & & \multicolumn{2}{|c|}{ DiD - $(\text { Total Debt } / T A)_{i t}$} & $\begin{array}{l}0.0259 * * * \\
0.0283 * * *\end{array}$ & \\
\hline
\end{tabular}




\section{Table 10: DiD Regression for Unlisted Companies.}

Table 10. reports the results of DiD regression results using the following general equation:

$$
(D e b t / T A)_{i t}=\alpha+\beta .\left[\text { CIC }_{i} \times \text { Post }_{t}\right]+\boldsymbol{X}_{i t} \cdot \boldsymbol{\delta}+\left[\boldsymbol{X}_{i t} \times \text { Post }_{t}\right] \cdot \boldsymbol{\vartheta}+\left[\boldsymbol{X}_{i t} \times C I C_{i}\right] \cdot \boldsymbol{\rho}+\gamma_{i}+\left[\eta_{j} \times \tau_{t}\right]+e_{i t}
$$

where $(D e b t / T A)_{i t}$ is defined as total debt to book value of total assets in models [1] and [2], secured debt to book value of total assets in models [3] and [4] and unsecured debt to book value of total assets in models [5] and [6]. CIC $_{i}$ is an indicator variable that takes the value of one for treated firms and zero otherwise. Post $t$ is a categorical variable that takes the value of one for years following and including the year of introduction of the SARFAESI Act, i.e., 2002, and zero otherwise. $\boldsymbol{X}_{\boldsymbol{i}}$ is a vector of control variables including Size, Tangibility, Operating Profitability, and Sales-growth, as defined in Table 1. $\gamma_{i}$ controls for the firm fixed effect. The interaction term $\left[\eta_{j} \times \tau_{t}\right]$ controls for time-variant industry-level shocks and $e_{i t}$ is the error term. Standard errors, clustered at the firm level, are reported in parentheses. Models [1], [3] and [5] report regression without control variables and models [2], [4] and [6] report regression with additional control variables. *,** and *** denote statistical significance at $10 \%, 5 \%$ and $1 \%$ levels respectively. The total sample period ranges from 1996 to 2007. Data source: CMIE database.

\begin{tabular}{|c|c|c|c|c|c|c|}
\hline & \multirow{2}{*}{\multicolumn{2}{|c|}{$\frac{\text { Total Debt }}{T A}$}} & \multirow{2}{*}{\multicolumn{2}{|c|}{$\frac{\text { Secured Debt }}{T A}$}} & \multirow{2}{*}{\multicolumn{2}{|c|}{$\frac{\text { Unsecured Debt }}{T A}$}} \\
\hline & & & & & & \\
\hline & {$[1]$} & [2] & {$[3]$} & [4] & {$[5]$} & [6] \\
\hline $\begin{array}{l}\mathrm{DiD} \\
{\left[\text { CIC }_{i} \times \text { Post }_{t}\right]}\end{array}$ & $\begin{array}{l}0.038 * * * \\
(0.0092)\end{array}$ & $\begin{array}{l}0.030 * * * \\
(0.0096)\end{array}$ & $\begin{array}{l}0.043 * * * \\
(0.0083)\end{array}$ & $\begin{array}{c}0.042 * * * \\
(0.0093)\end{array}$ & $\begin{array}{c}-0.024 * * * \\
(0.0081)\end{array}$ & $\begin{array}{c}-0.026 * * * \\
(0.0083)\end{array}$ \\
\hline Size & & $\begin{array}{c}0.001 \\
(0.0067)\end{array}$ & & $\begin{array}{c}0.021 * * * \\
(0.0068)\end{array}$ & & $\begin{array}{c}-0.047 * * * \\
(0.0069)\end{array}$ \\
\hline Tangibility & & $\begin{array}{l}0.214 * * * \\
(0.0263)\end{array}$ & & $\begin{array}{c}0.225 * * * \\
(0.0254)\end{array}$ & & $\begin{array}{c}0.032 \\
(0.0229)\end{array}$ \\
\hline Operating Profitability & & $\begin{array}{c}-0.096 * * * \\
(0.0264)\end{array}$ & & $\begin{array}{c}-0.102 * * * \\
(0.0251)\end{array}$ & & $\begin{array}{c}0.010 \\
(0.0242)\end{array}$ \\
\hline Sales-growth & & $\begin{array}{c}0.002 \\
(0.0013)\end{array}$ & & $\begin{array}{c}0.002 * \\
(0.0012)\end{array}$ & & $\begin{array}{c}0.000 \\
(0.0014)\end{array}$ \\
\hline Post $\times$ Size & & $\begin{array}{c}0.000 \\
(0.0032)\end{array}$ & & $\begin{array}{l}0.006 * * \\
(0.0029)\end{array}$ & & $\begin{array}{c}-0.009 * * * \\
(0.0030)\end{array}$ \\
\hline Post $\times$ Tangibility & & $\begin{array}{c}-0.019 \\
(0.0204)\end{array}$ & & $\begin{array}{c}0.001 \\
(0.0192)\end{array}$ & & $\begin{array}{c}-0.016 \\
(0.0187)\end{array}$ \\
\hline Post $\times$ Operating Profitability & & $\begin{array}{c}-0.181 * * * \\
(0.0263)\end{array}$ & & $\begin{array}{c}-0.160 * * * \\
(0.0257)\end{array}$ & & $\begin{array}{l}-0.053 * * \\
(0.0236)\end{array}$ \\
\hline Post $\times$ Sales-growth & & $\begin{array}{c}-0.000 \\
(0.0027)\end{array}$ & & $\begin{array}{c}-0.004 \\
(0.0027)\end{array}$ & & $\begin{array}{c}0.002 \\
(0.0027)\end{array}$ \\
\hline $\mathrm{CIC} \times$ Size & & $\begin{array}{c}-0.033 * * * \\
(0.0120)\end{array}$ & & $\begin{array}{c}-0.012 \\
(0.0095)\end{array}$ & & $\begin{array}{c}-0.012 \\
(0.0118)\end{array}$ \\
\hline $\mathrm{CIC} \times$ Tangibility & & $\begin{array}{c}-0.063 \\
(0.0403)\end{array}$ & & $\begin{array}{c}-0.034 \\
(0.0355)\end{array}$ & & $\begin{array}{c}-0.075 * * \\
(0.0381)\end{array}$ \\
\hline $\mathrm{CIC} \times$ Operating Profitability & & $\begin{array}{c}-0.009 \\
(0.0308)\end{array}$ & & $\begin{array}{l}0.062 * * \\
(0.0307)\end{array}$ & & $\begin{array}{l}-0.061 * * \\
(0.0303)\end{array}$ \\
\hline CIC $\times$ Sales-growth & & $\begin{array}{l}-0.003 * * \\
(0.0018)\end{array}$ & & $\begin{array}{c}-0.003 \\
(0.0018)\end{array}$ & & $\begin{array}{c}-0.001 \\
(0.0020)\end{array}$ \\
\hline Firm FE & Yes & Yes & Yes & Yes & Yes & Yes \\
\hline Industry FE $\times$ Year FE & Yes & Yes & Yes & Yes & Yes & Yes \\
\hline $\mathrm{R}^{2}$ (Adj.) & 0.79 & 0.80 & 0.75 & 0.77 & 0.77 & 0.79 \\
\hline No. of Firms & 8807 & 8807 & 7,833 & 7,833 & 7529 & 7529 \\
\hline No. of Obs. & 32.288 & 32,288 & 28,332 & 28,332 & 25.646 & 25.646 \\
\hline
\end{tabular}




\section{Table 11: Heterogeneity within Business Groups and Corporate Financing.}

Table 11 reports the results of DiDiD regression using the regression equation:

$$
\begin{aligned}
\left(\text { Debt }_{T} \text { TA }\right)_{i t}=\alpha & +\beta .\left[\text { NonFinConnect }_{i} \times \text { Post }_{t}\right] \\
& +\boldsymbol{X}_{\boldsymbol{i t}} \cdot \boldsymbol{\delta}+\left[\boldsymbol{X}_{\boldsymbol{i t}} \times \text { Post }_{t}\right] \cdot \boldsymbol{\vartheta}+\left[\boldsymbol{X}_{\boldsymbol{i t}} \times \text { NonFinConnect }_{i}\right] \cdot \boldsymbol{\rho}+\gamma_{i}+\left[\eta_{j} \times \tau_{t}\right]+e_{i t}
\end{aligned}
$$

where $(D e b t / T A)_{i t}$ is the dependent variable measuring different forms of corporate borrowing (Total, Secured and Unsecured) scaled by total assets (TA). NonFinConnect ${ }_{i}$ is an indicator variable that takes the value of one for business group firms with no affiliation with financial intermediaries and zero for those business group firms with an affiliation with financial intermediaries. Post $t$ is a categorical variable that takes the value of one for years following and including the year of introduction of the SARFAESI Act, i.e., 2002, and zero otherwise. $\boldsymbol{X}_{\boldsymbol{i t}}$ is a vector of control variables including Size, Tangibility, Operating Profitability and $M B$ as defined in Table 1. $\gamma_{i}$ controls for the firm fixed effect. The interaction term $\left[\eta_{j} \times \tau_{t}\right]$ controls for time-variant industry-level shocks and $e_{i t}$ is the error term. Standard errors, clustered at the firm level, are reported in parentheses. Models [1], [3] and [5] report regression without control variables and models [2], [4] and [6] report regression with additional control variables. *,** and *** denote statistical significance at $10 \%, 5 \%$ and $1 \%$ levels respectively. The sample period ranges from 1996 to

\begin{tabular}{|c|c|c|c|c|c|c|}
\hline & \multicolumn{2}{|c|}{$\frac{\text { Total Debt }}{T A}$} & \multicolumn{2}{|c|}{$\frac{\text { Secured Debt }}{T A}$} & \multicolumn{2}{|c|}{$\frac{\text { Unsecured Debt }}{T A}$} \\
\hline & [1] & [2] & [3] & [4] & [5] & [6] \\
\hline DiD & $0.0428 * * *$ & $0.0333 * * *$ & $0.0364 * * *$ & $0.0282 * * *$ & 0.0040 & 0.0060 \\
\hline NonFinConnect $_{i} \times$ Post $_{t}$ & $(0.0110)$ & $(0.0135)$ & $(0.0100)$ & $(0.0119)$ & $(0.0062)$ & $(0.0075)$ \\
\hline Tangibility & & $\begin{array}{c}0.0394 * * * \\
(0.0082)\end{array}$ & & $\begin{array}{c}0.0248 * * * \\
(0.0069)\end{array}$ & & $\begin{array}{c}0.0046 \\
(0.0071)\end{array}$ \\
\hline Size & & $\begin{array}{c}0.2163 * * * \\
(0.0280)\end{array}$ & & $\begin{array}{c}0.2190 * * * \\
(0.0262)\end{array}$ & & $\begin{array}{l}-0.0156 \\
(0.0190)\end{array}$ \\
\hline Operating Profitability & & $\begin{array}{c}-0.0119 * * * \\
(0.0037)\end{array}$ & & $\begin{array}{c}-0.0107 * * \\
(0.0053)\end{array}$ & & $\begin{array}{l}-0.0040 \\
(0.0052)\end{array}$ \\
\hline MB & & $\begin{array}{c}0.0095 * * * \\
(0.0014)\end{array}$ & & $\begin{array}{c}0.0068 * * * \\
(0.0013)\end{array}$ & & $\begin{array}{c}0.0032 * * * \\
(0.0009)\end{array}$ \\
\hline Post $\times$ Size & & $\begin{array}{l}-0.0017 \\
(0.0031)\end{array}$ & & $\begin{array}{l}-0.0024 \\
(0.0029)\end{array}$ & & $\begin{array}{l}-0.0011 \\
(0.0022)\end{array}$ \\
\hline Post $\times$ Tangibility & & $\begin{array}{l}-0.1187 * * * \\
(0.0252)\end{array}$ & & $\begin{array}{c}-0.0762 * * * \\
(0.0230)\end{array}$ & & $\begin{array}{c}-0.0432 * * \\
(0.0184)\end{array}$ \\
\hline Post $\times$ Profitability & & $\begin{array}{c}0.0073 \\
(0.0047)\end{array}$ & & $\begin{array}{l}0.0123 * * \\
(0.0057)\end{array}$ & & $\begin{array}{l}-0.0020 \\
(0.0062)\end{array}$ \\
\hline Post $\times \mathrm{MB}$ & & $\begin{array}{l}-0.0040 * * \\
(0.0017)\end{array}$ & & $\begin{array}{l}-0.0032 * \\
(0.0017)\end{array}$ & & $\begin{array}{c}0.0000 \\
(0.0015)\end{array}$ \\
\hline NonFinConnect $\times$ Size & & $\begin{array}{l}-0.0136 \\
(0.0145)\end{array}$ & & $\begin{array}{l}-0.0080 \\
(0.0127)\end{array}$ & & $\begin{array}{l}-0.0101 \\
(0.0098)\end{array}$ \\
\hline NonFinConnect $\times$ Tangibility & & $\begin{array}{l}-0.0103 \\
(0.0587)\end{array}$ & & $\begin{array}{l}-0.0251 \\
(0.0533)\end{array}$ & & $\begin{array}{c}0.0202 \\
(0.0296)\end{array}$ \\
\hline NonFinConnect $\times$ Profitability & & $\begin{array}{l}-0.0198 \\
(0.0123)\end{array}$ & & $\begin{array}{c}-0.0312 * * * \\
(0.0113)\end{array}$ & & $\begin{array}{l}-0.0009 \\
(0.0055)\end{array}$ \\
\hline NonFinConnect $\times \mathrm{MB}$ & & $\begin{array}{c}0.0058 * * * \\
(0.0020)\end{array}$ & & $\begin{array}{c}0.0045 * * \\
(0.0021)\end{array}$ & & $\begin{array}{c}0.0005 \\
(0.0018)\end{array}$ \\
\hline Firm FE & Yes & Yes & Yes & Yes & Yes & Yes \\
\hline Industry FE $\times$ Year FE & Yes & Yes & Yes & Yes & Yes & Yes \\
\hline $\mathrm{R}^{2}$ (Adj.) & 0.73 & 0.75 & 0.71 & 0.73 & 0.49 & 0.51 \\
\hline No. of Firms & 1,978 & 1,978 & 1,897 & 1,897 & 1,772 & 1,772 \\
\hline No. of Obs. & 15,128 & 15,128 & 14,366 & 14,366 & 12,235 & 12,235 \\
\hline
\end{tabular}
2007. Data source: CMIE database. 
Table 12: Univariate analysis of Before and After of Net Receiving and Net Supplying firms.

Table 12 presents comparative univariate statistics (mean) of Secured Debt/TA, Unsecured Debt/TA and Total Debt/TA before (1996-2001) and after (2002-2007) the SARFAESI Act for the business group firms which are net suppliers and borrowers of intra-group loans. $* * *$ and $* * *$ denote statistical significance at $10 \%, 5 \%$ and $1 \%$ levels respectively. The sample period ranges from 1996 to 2007. Data source: CMIE database.

\begin{tabular}{lcccccc}
\hline Dependent Variable & Supplier / receiver & $\begin{array}{c}\text { Before } \\
\text { (b) }\end{array}$ & $\begin{array}{c}\text { After } \\
\text { (a) }\end{array}$ & Observations. & Difference (a-b) & t-stat \\
\hline Secured D/TA & Supplier & 0.2914 & 0.2894 & 3777 & -0.0020 & -0.8334 \\
& Receiver & 0.3191 & 0.2835 & 1261 & $-0.0356^{* * *}$ & -2.5362 \\
Unsecured D/TA & Supplier & 0.1394 & 0.1512 & 3628 & $0.0118^{* * *}$ & 2.5101 \\
& Receiver & 0.1427 & 0.1717 & 1626 & $0.0290 * * *$ & 3.5029 \\
Total Debt/TA & Supplier & 0.3753 & 0.3809 & 4126 & $0.0056^{* *}$ & 2.0713 \\
& Receiver & 0.3705 & 0.3677 & 1780 & $-0.0028^{* *}$ & -2.0005 \\
\hline
\end{tabular}




\section{Table 13: Implications}

Table 13 reports the implications of improved access to finance among firms having constrained access to internal capital following improvement in creditor rights given using the following model:

$$
\begin{aligned}
\text { Implication }_{i, t+1}= & \alpha+\beta .\left[\text { CIC }_{i} \times \text { Post }_{t}\right]+\boldsymbol{X}_{i t} \cdot \boldsymbol{\delta}+\left[\boldsymbol{X}_{i t} \times \text { Post }_{t}\right] \cdot \boldsymbol{\vartheta}+\left[\boldsymbol{X}_{i t} \times \text { CIC }_{i}\right] \cdot \boldsymbol{\rho}+ \\
& \gamma_{i}+\left[\eta_{j} \times \tau_{t}\right]+e_{i t}
\end{aligned}
$$

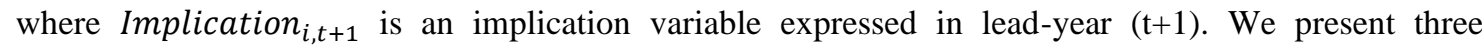
implication variables: Capex, $R o A$, and $M B$. For a year $t$, we calculate Capex for a firm $i$ as an addition to fixed assets scaled by the book value of total assets. $R o A$ is computed as earnings before interest and taxes (EBIT) scaled by the book value of total assets. $M B$ is defined as the ratio of market to book value of equity. $C I C_{i}$ is an indicator variable that takes the value of one for treated firms and zero otherwise. Post $t_{t}$ is a categorical variable that takes the value of one for years following and including the year of introduction of the SARFAESI Act, i.e., 2002, and zero otherwise. Firm controls include Size, Tangibility and Operating Profitability (except model [2]) are as defined in Table 1. $\gamma_{i}$ controls for the firm fixed effect. The interaction term $\left[\eta_{j} \times \tau_{t}\right]$ controls for time-variant industry-level shocks and $e_{i t}$ is the error term. Standard errors, clustered at the firm level, are reported in parentheses. *, ** and *** denote statistical significance at 10\%, 5\% and 1\% levels respectively. The sample period ranges from 1996 to

\begin{tabular}{|c|c|c|c|}
\hline & Capex(lead) & RoA(lead) & MB(lead) \\
\hline & [1] & [2] & [3] \\
\hline DiD & $0.024 * * *$ & $0.013 * * *$ & $0.009 * *$ \\
\hline$\left[\right.$ CIC $_{i} \times$ Post $\left._{t}\right]$ & $(0.0044)$ & $(0.0046)$ & $(0.0041)$ \\
\hline \multirow[t]{2}{*}{ Size } & $0.076 * * *$ & $-0.016 * * *$ & $-0.016 * * *$ \\
\hline & $(0.0041)$ & $(0.0037)$ & $(0.0030)$ \\
\hline \multirow[t]{2}{*}{ Tangibility } & $0.421 * * *$ & $0.049 * * *$ & $-0.067 * * *$ \\
\hline & $(0.0187)$ & $(0.0119)$ & $(0.0100)$ \\
\hline \multirow[t]{2}{*}{ Operating Profitability } & $0.005 * * *$ & & 0.001 \\
\hline & $(0.0017)$ & & $(0.0016)$ \\
\hline \multirow[t]{2}{*}{ Post $\times$ Size } & $-0.017 * * *$ & -0.001 & 0.000 \\
\hline & $(0.0013)$ & $(0.0013)$ & $(0.0012)$ \\
\hline \multirow[t]{2}{*}{ Post $\times$ Tangibility } & $-0.043 * * *$ & $0.024 * * *$ & $0.032 * * *$ \\
\hline & $(0.0106)$ & $(0.0093)$ & $(0.0076)$ \\
\hline \multirow[t]{2}{*}{ Post $\times$ Operating Profitability } & 0.000 & & 0.008 \\
\hline & $(0.0003)$ & & $(0.0063)$ \\
\hline \multirow[t]{2}{*}{$\mathrm{CIC} \times$ Size } & $-0.015 * *$ & 0.005 & $0.009 * *$ \\
\hline & $(0.0058)$ & $(0.0047)$ & $(0.0037)$ \\
\hline \multirow[t]{2}{*}{ CIC $\times$ Tangibility } & $-0.062 * *$ & -0.022 & 0.005 \\
\hline & $(0.0257)$ & $(0.0155)$ & $(0.0131)$ \\
\hline \multirow[t]{2}{*}{$\mathrm{CIC} \times$ Operating Profitability } & -0.004 & & -0.021 \\
\hline & $(0.0024)$ & & $(0.0239)$ \\
\hline Firm FE & Yes & Yes & Yes \\
\hline Industry FE ×Year FE & Yes & Yes & Yes \\
\hline $\mathrm{R}^{2}$ (Adj.) & 0.26 & 0.49 & 0.42 \\
\hline No. of Firms & 4,075 & 4,075 & 4,075 \\
\hline No. of Obs. & 26,861 & 26,861 & 26,861 \\
\hline
\end{tabular}
2007. Source: CMIE database 


\section{Figure 1: Time-series plot of treated and comparison firms.}

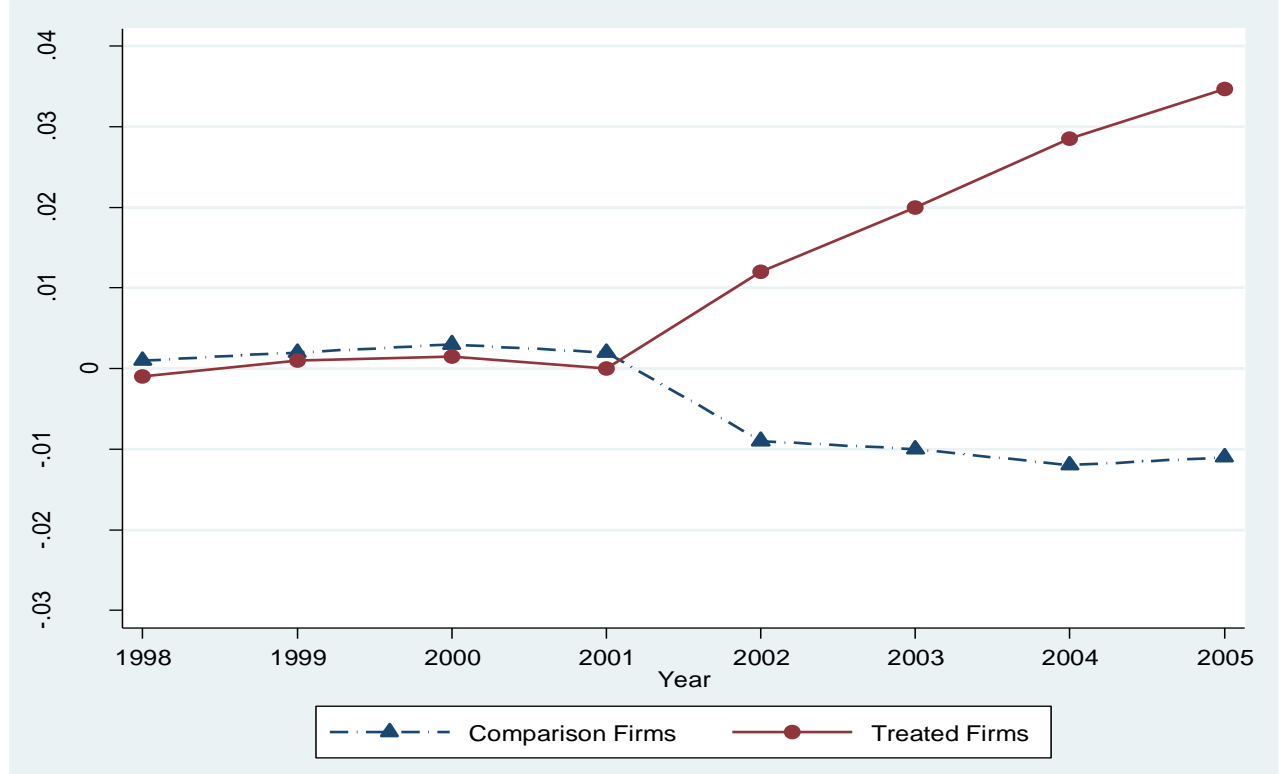

Note: Figure 1 presents the yearly rescaled average values of Total Debt/TA (total borrowing scaled by the book value of total assets) for the entire sample by treated and comparison firms. For each year the rescaling is done by deducting the three-year average before the SARFAESI reform (i.e., an average of 1998-2000) from each annual average figure of Total Debt/TA. The treated firms are standalone Indian firms having constrained access to internal capital and comparison firms are business group firms with higher access to internal capital. The sample period is 1998 to 2005. Source: CMIE database. 
Figure 2: Time-series plot of matched treated and comparison firms.

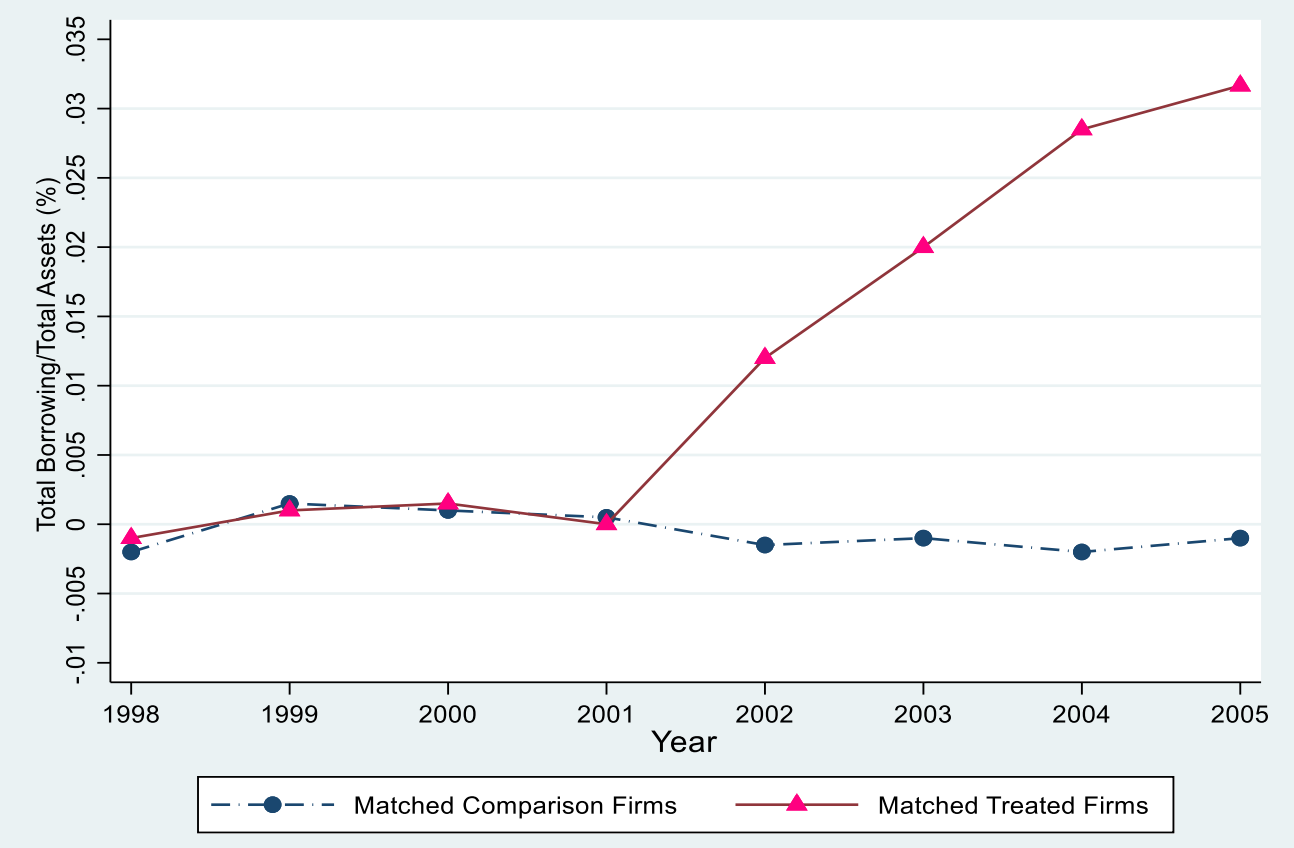

Note: Figure 2 presents the yearly rescaled average values of Total Debt/TA (total borrowing scaled by the book value of total assets) for the propensity score matched sample of treated and comparison firms. For each year the rescaling is done by deducting the three-year average before the SARFAESI reform (i.e., an average of 1998-2000) from each annual average figure of Total Debt/TA. The treated firms are standalone Indian firms having constrained access to internal capital and comparison firms are business group firms with higher access to internal capital. The sample period is 1998 to 2005. Source: CMIE database. 


\section{Appendix}

Table A1: Industry classification.

\begin{tabular}{|c|c|c|c|}
\hline $\begin{array}{c}7 \text { Digit } \\
\text { Prowess Code }\end{array}$ & Industry Clusters & $\begin{array}{c}\text { Number of } \\
\text { Observations }\end{array}$ & Percentage \\
\hline 1010111 & Agricultural product and food & 3,652 & $8.32 \%$ \\
\hline 1010115 & Cloth and textile & 4,359 & $9.93 \%$ \\
\hline 1010120 & Chemicals, drugs, and Pharmaceuticals & 7,133 & $16.26 \%$ \\
\hline 1010125 & Consumer electronics, cosmetics, toiletries etc. & 1,524 & $3.47 \%$ \\
\hline 1010130 & Cements and Construction materials & 1,667 & $3.80 \%$ \\
\hline 1010135 & Metals and Steel & 3,359 & $7.66 \%$ \\
\hline 1010140 & Machinery, wires and cables & 3,140 & $7.16 \%$ \\
\hline 1010145 & Vehicles and automobile ancillaries & 1,764 & $4.02 \%$ \\
\hline 1010150 & Paper, glasses and media prints & 1,303 & $2.97 \%$ \\
\hline 1010155 & Diversified & 989 & $2.25 \%$ \\
\hline 1010201 & Coal and lignite & 54 & $0.12 \%$ \\
\hline 1010202 & Crude oil \& natural gas & 38 & $0.09 \%$ \\
\hline 1010203 & Minerals & 303 & $0.69 \%$ \\
\hline 1010301 & Conventional and Renewable electricity & 233 & $0.53 \%$ \\
\hline 1010302 & Electricity transmission \& distribution & 43 & $0.10 \%$ \\
\hline 1010401 & Hotels and Tourism & 811 & $1.85 \%$ \\
\hline 1010404 & Trading (Wholesale and retails) & 5,645 & $12.87 \%$ \\
\hline 1010405 & Transport & 429 & $0.98 \%$ \\
\hline 1010406 & Telecommunication and Courier services & 188 & $0.43 \%$ \\
\hline 1010408 & Computer and Its & 1,505 & $3.43 \%$ \\
\hline 1010415 & $\begin{array}{l}\text { Movies, animations, business consultancies other } \\
\text { miscellaneous services }\end{array}$ & 3,489 & $7.95 \%$ \\
\hline 1010601 & Commercial complexes and Housing Constructions & 444 & $1.01 \%$ \\
\hline 1010602 & Industrial and Infrastructural constructions & 1,805 & $4.11 \%$ \\
\hline Total & & 43,877 & $100.00 \%$ \\
\hline
\end{tabular}




\section{Table A2: Robustness Test with Standard Error Clustered at Business-group Level}

Table A2 reports the results of DiD regression using the following general specification:

$$
(\text { Total Debt } / \text { TA })_{i t}=\alpha+\beta \cdot\left[\text { CIC }_{i} \times \text { Post }_{t}\right]+\boldsymbol{X}_{i t} \cdot \boldsymbol{\delta}+\left[\boldsymbol{X}_{i t} \times \text { Post }_{t}\right] \cdot \boldsymbol{\vartheta}+\left[\boldsymbol{X}_{i t} \times C I C_{i}\right] \cdot \boldsymbol{\rho}+\gamma_{i}+\left[\eta_{j} \times \tau_{t}\right]+e_{i t}
$$

where $(\text { Total Debt/TA })_{i t}$ is defined as total debt to book value of total assets in models [1] to [4] and TD_Growth is defined as the growth in total debt in the model [5]. CIC $i$ is an indicator variable that takes the value of one for treated firms (standalone firms) and zero otherwise (business group affiliated firms). Post $t_{t}$ is a categorical variable that takes the value of one for years following and including the year of introduction of the SARFAESI Act, i.e., 2002, and zero otherwise. $\boldsymbol{X}_{i t}$ is a vector of control variables including Size, Tangibility, Operating Profitability, and $M B$, as defined in Table $1 . \gamma_{i}$ controls for the firm fixed effect. The interaction term $\left[\eta_{j} \times \tau_{t}\right]$ controls for time-variant industry-level shocks and $e_{i t}$ is the error term. Standard errors are clustered at business group level (with 3712 unique clusters including 641 unique business groups and 3071 unique clusters for stand-alone firms), and are reported in parentheses. The entire study period ranges from 1996 to 2007 whereas the shorter study period is from 1998 to 2005. Models [1] [2] [6] and [7] report regression without control variables and all other models report regression with control variables. *, ** and $* * *$ denote statistical significance at $10 \%, 5 \%$ and $1 \%$ levels respectively. Source: CMIE database

\begin{tabular}{|c|c|c|c|c|c|c|c|c|c|c|}
\hline & \multicolumn{5}{|c|}{ Study Period (1996-2007) } & \multicolumn{5}{|c|}{ Study Period (1998-2005) } \\
\hline & \multicolumn{4}{|c|}{ Total Debt/TA } & \multirow{2}{*}{$\begin{array}{c}\text { TD_Growth } \\
{[5]}\end{array}$} & \multicolumn{4}{|c|}{ Total Debt/TA } & \multirow{2}{*}{$\begin{array}{c}\text { TD_Growth } \\
{[10]}\end{array}$} \\
\hline & [1] & {$[2]$} & [3] & [4] & & [6] & [7] & {$[8]$} & [9] & \\
\hline $\begin{array}{l}\mathrm{DiD} \\
{\left[\text { CIC }_{i} \times \text { Post }_{t}\right]}\end{array}$ & $\begin{array}{c}0.040 * * * \\
(0.0109)\end{array}$ & $\begin{array}{c}0.025^{* * * *} \\
(0.0089)\end{array}$ & $\begin{array}{c}0.031 * * * \\
(0.0082)\end{array}$ & $\begin{array}{c}0.026^{* * * *} \\
(0.0079)\end{array}$ & $\begin{array}{c}0.047 * * * \\
(0.0173)\end{array}$ & $\begin{array}{c}0.028 * * * \\
(0.0080)\end{array}$ & $\begin{array}{c}0.020 * * * \\
(0.0064)\end{array}$ & $\begin{array}{c}0.024 * * * \\
(0.0059)\end{array}$ & $\begin{array}{c}0.026^{* * * *} \\
(0.0081)\end{array}$ & $\begin{array}{c}0.074 * * * \\
(0.0222)\end{array}$ \\
\hline Size & & & $\begin{array}{c}0.028 * * * \\
(0.0046)\end{array}$ & $\begin{array}{c}0.031 * * * \\
(0.0025)\end{array}$ & $\begin{array}{c}0.043 * * * \\
(0.0159)\end{array}$ & & & $\begin{array}{c}0.010 * \\
(0.0060)\end{array}$ & $\begin{array}{c}0.013 * * * \\
(0.0046)\end{array}$ & $\begin{array}{c}0.031 \\
(0.0355)\end{array}$ \\
\hline Tangibility & & & $\begin{array}{c}0.195 * * * \\
(0.0152)\end{array}$ & $\begin{array}{c}0.247 * * * \\
(0.0177)\end{array}$ & $\begin{array}{c}0.125^{* * * *} \\
(0.0226)\end{array}$ & & & $\begin{array}{c}0.201 * * * \\
(0.0181)\end{array}$ & $\begin{array}{c}0.256^{* * * *} \\
(0.0208)\end{array}$ & $\begin{array}{c}0.149 * * * \\
(0.0294)\end{array}$ \\
\hline $\begin{array}{l}\text { Operating } \\
\text { Profitability }\end{array}$ & & & $\begin{array}{c}-0.010 * * * \\
(0.0014)\end{array}$ & $\begin{array}{c}-0.007 * * * \\
(0.0005)\end{array}$ & $\begin{array}{c}-0.029 * * * \\
(0.0041)\end{array}$ & & & $\begin{array}{c}-0.010 * * * \\
(0.0020)\end{array}$ & $\begin{array}{c}-0.005^{* * *} \\
(0.0010)\end{array}$ & $\begin{array}{c}-0.032 * * * \\
(0.0027)\end{array}$ \\
\hline MB & & & $\begin{array}{c}0.008 * * * \\
(0.0006)\end{array}$ & $\begin{array}{c}0.014 * * * \\
(0.0011)\end{array}$ & $\begin{array}{c}-0.003 * * \\
(0.0015)\end{array}$ & & & $\begin{array}{c}0.008 * * * \\
(0.0006)\end{array}$ & $\begin{array}{c}0.011 * * * \\
(0.0014)\end{array}$ & $\begin{array}{c}-0.005 * * \\
(0.0018)\end{array}$ \\
\hline Post $\times$ Size & & & & $\begin{array}{c}-0.004 * * \\
(0.0017)\end{array}$ & $\begin{array}{c}0.003 \\
(0.0055)\end{array}$ & & & & $\begin{array}{c}-0.002 \\
(0.0020)\end{array}$ & $\begin{array}{c}0.011 \\
(0.0078)\end{array}$ \\
\hline Post $\times$ Tangibility & & & & $\begin{array}{c}-0.099 * * * \\
(0.0111)\end{array}$ & $\begin{array}{c}-0.098 * * * \\
(0.0329)\end{array}$ & & & & $\begin{array}{c}-0.094 * * * \\
(0.0133)\end{array}$ & $\begin{array}{c}-0.048 \\
(0.0341)\end{array}$ \\
\hline
\end{tabular}




\begin{tabular}{|c|c|c|c|c|c|c|c|c|c|c|}
\hline \multirow{2}{*}{$\begin{array}{l}\text { Post } \times \text { Operating } \\
\text { Profitability }\end{array}$} & & & & $-0.006 * * *$ & $-0.019 * * *$ & & & & $-0.006 * * *$ & $-0.016 * * *$ \\
\hline & & & & $(0.0008)$ & $(0.0042)$ & & & & $(0.0010)$ & $(0.0046)$ \\
\hline Post $\times$ MB & & & & $\begin{array}{c}-0.006 * * * \\
(0.0011)\end{array}$ & $\begin{array}{c}-0.001 \\
(0.0031)\end{array}$ & & & & $\begin{array}{l}-0.003 * \\
(0.0016)\end{array}$ & $\begin{array}{c}0.003 \\
(0.0038)\end{array}$ \\
\hline $\mathrm{CIC} \times$ Size & & & & $\begin{array}{c}0.002 \\
(0.0066)\end{array}$ & $\begin{array}{c}0.023 \\
(0.0145)\end{array}$ & & & & $\begin{array}{c}-0.001 \\
(0.0105)\end{array}$ & $\begin{array}{c}0.048 \\
(0.0396)\end{array}$ \\
\hline CIC $\times$ Tangibility & & & & $\begin{array}{c}-0.030 \\
(0.0281)\end{array}$ & $\begin{array}{c}-0.090 \\
(0.0593)\end{array}$ & & & & $\begin{array}{c}-0.044 \\
(0.0335)\end{array}$ & $\begin{array}{c}-0.125 \\
(0.0984)\end{array}$ \\
\hline \multirow{2}{*}{$\begin{array}{l}\mathrm{CIC} \times \text { Operating } \\
\text { Profitability }\end{array}$} & & & & -0.004 & -0.001 & & & & $-0.006^{*}$ & -0.007 \\
\hline & & & & $(0.0031)$ & $(0.0125)$ & & & & $(0.0033)$ & $(0.0161)$ \\
\hline $\mathrm{CIC} \times \mathrm{MB}$ & & & & $\begin{array}{c}-0.003 * * * \\
(0.0009)\end{array}$ & $\begin{array}{c}-0.000 \\
(0.0024)\end{array}$ & & & & $\begin{array}{l}-0.002 * \\
(0.0010)\end{array}$ & $\begin{array}{c}-0.005 \\
(0.0035)\end{array}$ \\
\hline Firm FE & Yes & Yes & Yes & Yes & Yes & Yes & Yes & Yes & Yes & Yes \\
\hline $\begin{array}{l}\text { Industry FE } \times \text { Year } \\
\text { FE }\end{array}$ & Yes & Yes & Yes & Yes & Yes & Yes & Yes & Yes & Yes & Yes \\
\hline $\mathrm{R}^{2}$ (Adj.) & 0.73 & 0.70 & 0.72 & 0.72 & 0.19 & 0.81 & 0.78 & 0.79 & 0.80 & 0.22 \\
\hline No. of Firms & 5,049 & 3,764 & 3,764 & 3,747 & 3,714 & 4,535 & 2,896 & 2,896 & 2,896 & 2845 \\
\hline No. of Obs. & 43,611 & 26,638 & 26,638 & 26,638 & 26,302 & 28,533 & 16,411 & 16,411 & 16,411 & 16,127 \\
\hline
\end{tabular}




\section{Table A3: DiD Regression based on Tangibility Tercile.}

Table A3 reports the results of $\mathrm{DiD}$ regression using the regression equation:

$$
(\text { Total Debt } / \text { TA })_{i t}=\alpha+\beta \cdot\left[\text { High Tang }_{i} \times \text { Post }_{t}\right]+\boldsymbol{X}_{i t} \cdot \boldsymbol{\delta}+\left[\boldsymbol{X}_{i t} \times \text { Post }_{t}\right] \cdot \boldsymbol{\vartheta}+\gamma_{i}+\left[\eta_{j} \times \tau_{t}\right]+e_{i t}
$$

where (Total Debt/TA $)_{i t}$ is the dependent variable measuring corporate borrowing. $C_{i} C_{i}$ is an indicator variable that takes the value of one for treated firms and zero otherwise. Post $t$ is a categorical variable that takes the value of one for years following and including the year of introduction of the SARFAESI Act, i.e., 2002 (SA), and zero otherwise. High Tang is a categorical variable that takes a value of one for the firms falling in the upper tercile based on a three year average of firm tangibility before the SARFAESI Act, i.e., from 1999 to 2001 and zero for the firms falling in the lower tercile. $\boldsymbol{X}_{\boldsymbol{i}}$ is a vector of control variables including Size, Operating Profitability, and $M B$ as defined in the Table 1. $\gamma_{i}$ controls for the firm fixed effect. The interaction term $\left[\eta_{j} \times \tau_{t}\right]$ controls for time-variant industry-level shocks. $e_{i t}$ is the error term. Standard errors, clustered at the firm level, are reported in parentheses. $*, * *$ and $* * *$ denote statistical significance at $10 \%, 5 \%$ and $1 \%$ levels respectively. The sample period in the model [1] is from 1996 to 2007. For models [2] to [4], we report DiD for shorter periods. Model [5] represents the sample period of Vig (2013). Source: CMIE database.

\begin{tabular}{|c|c|c|c|c|c|}
\hline & [1] & [2] & [3] & [4] & [5] \\
\hline & {$[\mathrm{SA} \pm 6$ year $]$} & {$[\mathrm{SA} \pm 5$ year $]$} & {$[\mathrm{SA} \pm 4$ year $]$} & {$[\mathrm{SA} \pm 3$ year $]$} & $1997-2004$ \\
\hline DiD-Tangibility-Tercile & $-0.030 * * *$ & $-0.038 * * *$ & $-0.038 * * *$ & $-0.032 * * *$ & $-0.030 * * *$ \\
\hline$\left[\right.$ High Tang $_{i} \times$ Post $\left._{t}\right]$ & $(0.0072)$ & $(0.0073)$ & $(0.0072)$ & $(0.0069)$ & $(0.0074)$ \\
\hline \multirow[t]{2}{*}{ Size } & $0.031 * * *$ & $0.025 * * *$ & 0.008 & -0.004 & 0.005 \\
\hline & $(0.0059)$ & $(0.0070)$ & $(0.0080)$ & $(0.0099)$ & $(0.0083)$ \\
\hline \multirow[t]{2}{*}{ Operating Profitability } & $-0.005 * * *$ & $-0.005 * * *$ & $-0.004^{* *}$ & -0.001 & $-0.006 * * *$ \\
\hline & & & $(0.0018)$ & & \\
\hline \multirow[t]{2}{*}{ MB } & $0.009 * * *$ & $0.008 * * *$ & $0.007 * * *$ & $0.006 * * *$ & $0.008 * * *$ \\
\hline & $(0.0013)$ & $(0.0014)$ & $(0.0014)$ & $(0.0016)$ & $(0.0015)$ \\
\hline \multirow[t]{2}{*}{ Post $\times$ Size } & $-0.006 * * *$ & $-0.005 * *$ & $-0.004 *$ & -0.002 & -0.003 \\
\hline & $(0.0023)$ & $(0.0023)$ & $(0.0022)$ & $(0.0021)$ & $(0.0023)$ \\
\hline \multirow[t]{2}{*}{ Post $\times$ Operating Profitability } & $-0.006 * * *$ & $-0.005 * * *$ & $-0.006 * * *$ & $-0.006 * * *$ & $-0.005 * * *$ \\
\hline & $(0.0013)$ & $(0.0014)$ & $(0.0015)$ & $(0.0015)$ & $(0.0017)$ \\
\hline \multirow[t]{2}{*}{ Post $\times$ MB } & $-0.004 * *$ & -0.002 & 0.000 & 0.002 & 0.000 \\
\hline & $(0.0016)$ & $(0.0017)$ & $(0.0018)$ & $(0.0019)$ & $(0.0020)$ \\
\hline Firm FE & Yes & Yes & Yes & Yes & Yes \\
\hline Industry FE $\times$ Year FE & Yes & Yes & Yes & Yes & Yes \\
\hline $\mathrm{R}^{2}$ (Adj.) & 0.74 & 0.77 & 0.81 & 0.84 & 0.80 \\
\hline No. of Obs. & 16,716 & 13,431 & 10,405 & 7,720 & 11,066 \\
\hline
\end{tabular}

